\title{
MAIS DO BOM NÃO FAZ BEM: PROBLEMAS DO REFORÇO LIVRE
}

\author{
FREE REINFORCEMENT PROBLEMS
}

\author{
HÉLIO JOSÉ GUILHARDI - ORCID 0000-0003-4490-9585 \\ INSTITUTO DE TERAPIA POR CONTINGENCIAS DE REFORÇAMENTO, BRASIL
}

\begin{abstract}
RESUMO
Skinner $(1986,1987)$ escreveu sobre os dois efeitos do reforçamento: fortalecimento e prazer. Na sociedade ocidental as práticas culturais têm substituído a função de fortalecimento pela de prazer, quando os reforços são dados sem relação de contingência com os comportamentos. Relações entre comportamento e consequência, que acontecem apenas por contiguidade, dão origem a amplas e variadas classes de respostas chamadas "supersticiosas", que são mantidas pela satisfação que produzem, em detrimento da função de fortalecimento. Perde-se, assim, a relação entre o organismo e o ambiente própria do paradigma operante, no qual comportamento produz consequências que selecionam os comportamentos que as produzem. Quando os reforços são dados de modo arbitrário e livre o Ser Humano reduz seu repertório de comportamentos operantes produtivos e aumenta a dependência de reforços mediados por outras pessoas; torna-se assim dependente do outro e busca prioritariamente consequências prazerosas. Tais consequências são prejudiciais para o desenvolvimento do indivíduo que tende a se tornar apático, deprimido, dependente de pessoas, reivindicador, insatisfeito com a vida e, como consequência, o grupo social também perde, pois a estabilidade e progresso dele dependem da participação ativa, cooperativa e construtiva de seus membros. Muitos dos problemas comportamentais e afetivos da sociedade atual decorrem do excesso de reforço livre, que resulta em satisfação efêmera e déficit comportamental generalizado, que têm prevalecido nas práticas parentais e educacionais do mundo pós-moderno.

Palavras-chave: reforço livre, comportamento supersticioso, prazer e fortalecimento em relações operantes, práticas culturais deletérias.
\end{abstract}

\begin{abstract}
Skinner $(1987,1986)$ wrote about the two effects of reinforcement: strengthening and pleasure. In Western society cultural practices have replaced the strengthing function for the pleasure function, when reinforcers are given with no relation to behaviors. Correlations between behavior and consequence, when they happen only due to contiguity, originate large and varied classes of responses, named as "superstitious", maintained by the satisfaction they produce although with no strengthening function. Thus, the relation between organism and environment - characteristic to the operant paradigm, in which behavior produces consequences that in turn select the behaviors that produce these consequences - is lost. When reinforcers are given in an arbitrary and free way, the person has his repertoire of productive operant behaviors reduced, and the dependence on reinforcers mediated by others is increased; thus the person becomes dependent on others and seeks primarily pleasurable consequences. These consequences are harmful to the development of the individual, that will tend to become apathetic, depressed, dependent on other people, demanding, unhappy about his life; the person also looses his social group, since stability and progress of the group depend on the active, cooperative and constructive participation of its members. Many of the behavioral and affective problems of modern society come from an excess of free reinforcement, which results in the transitory satisfaction typical of parental and educational practices in the post-modern world.

Key words: free reinforcement, superstitious behavior, pleasure and strengthening in operant relations, deleterious cultural practices.
\end{abstract}

Este trabalho é baseado no texto intitulado "Reforço livre", previamente publicado no site do ITCR: $\langle$ http://www.itcrcampinas.com.br/txt/reforcolivre.pdf >. Correspondência deve ser enviada a Hélio Guilhardi pelo e-mail guilhardi@yahoo.com.br

DOI. 10.18542/rebac.v14i2.7537 
Iniciamos este texto com uma citação de Skinner $(1986 / 1987)^{1}$, que estará subjacente aos argumentos desenvolvidos ao longo deste artigo. Assim:

"Correndo o risco de ser seriamente mal interpretado pelos críticos do behaviorismo, farei distinção entre os efeitos de prazer e de fortalecimento [do reforçamento]. Eles ocorrem em diferentes momentos e são sentidos como coisas diferentes. Quando nos sentimos satisfeitos (pleased) não estamos necessariamente sentindo uma maior inclinação para nos comportarmos da mesma maneira. Quando repetimos comportamento que tem sido reforçado, por outro lado, nós não sentimos o efeito prazeroso que sentimos no momento em que o reforçamento ocorreu. [...] Acredito que práticas culturais se desenvolveram primariamente por causa do efeito de prazer do reforçamento e que muito do efeito de fortalecimento das consequências de reforçamento se perderam." (p. 17, negritos acrescentados).

A citação de Skinner permite uma compreensão abrangente e cada vez mais atual de problemas comportamentais que atingem jovens e aqueles que fazem parte significativa da vida deles: pais, parentes, amigos, educadores, líderes religiosos, bem como psicólogos, psiquiatras e outros profissionais. Neste artigo, apresentaremos algumas análises e interpretações derivadas, das danosas consequências do reforço livre que atinge indivíduos e, como decorrência, o grupo cultural a que pertencem como um todo, pois "Nem felicidade, nem a sobrevivência do grupo dependem da satisfação derivada de ter coisas." (Skinner, 1975/1978, p. 47).

Skinner $(1986,1987)$ prosseguiu com suas interpretações sobre alguns perigos — nada desprezíveis -, que surgiram com a evolução do condicionamento operante, em particular aqueles decorrentes dos efeitos de prazer. Assim:

"A espécie humana deu um passo evolucionário único quando sua musculatura vocal ficou sob controle operante e a linguagem nasceu. As pessoas poderiam então dizer, assim como mostrar, umas às outras o que fazer. Ambientes sociais extraordinariamente complexos, ou culturas, evoluíram e eles deram à espécie seu poder extraordinário. Acredito que, ao mesmo tempo, muitas das novas práticas culturais corroeram ou destruíram certas relações entre organismo e ambiente que prevaleciam quando o condicionamento operante surgiu. O resultado é facilmente descrito como tendo a ver com sentimentos porque os

\footnotetext{
${ }^{1}$ A primeira data refere-se à publicação original e a segunda, à publicação consultada.
}

sentimentos em discussão são intimamente ligados a reforçamento operante. Assim, dizemos que coisas reforçadoras nos agradam, que gostamos delas, que nos fazem sentirmo-nos bem. A associação de reforçamento com sentimento é tão forte que há muito se diz que coisas reforçam porque nos fazem sentirmo-nos bem ou nos sentimos bem porque nos reforçam. Deveríamos dizer, diferentemente, que coisas fazem nos sentirmos bem e reforçam por causa do que aconteceu na evolução da espécie". (pp. 16-17)

Skinner (1986/1987) usou o exemplo do comportamento de comer para ilustrar os dois efeitos do reforçamento:

"O tema de ter prazer ou satisfação [ao saborear comidas] presumivelmente surgiu [no processo evolutivo] quando os organismos se tornaram suscetíveis ao reforçamento pelas mesmas comidas. Eles então comeram por duas razões: o comportamento era inato e era também reforçado por suas consequências. É o efeito reforçador, não a tendência genética para comer, que nós relatamos quando dizemos que comidas 'são saborosas"”. (p. 17)

A distinção entre efeitos de prazer e de fortalecimento, proposta por Skinner, merece alguns esclarecimentos. Se analisarmos o que ocorre com o trabalhador assalariado de uma indústria e o ganho de um artesão, a distinção torna-se clara. $\mathrm{O}$ assalariado sente prazer quando recebe seu salário no fim do mês por duas razões: com esse dinheiro ele pode ter acesso a bens que o satisfazem ou lhe causam prazer (efeito de reforçamento positivo); adicionalmente, com esse dinheiro ele pode pagar um lugar para morar, comprar comida para si e seus familiares, vestir-se de forma confortável no frio e no calor, quem sabe comprar remédios etc., que reduzem as adversidades da vida; neste caso, deveríamos dizer que os sentimentos são de alívio, não de prazer (efeito de reforçamento negativo). Infelizmente, a realidade mostra que a maioria dos trabalhadores só tem acesso - se tanto à segunda alternativa.

O salário tem como principal função para eles proporcionar minimamente condição para sobreviver, o que os obriga a voltar diariamente para sua bancada de trabalho até o próximo salário: efeito de fortalecimento do comportamento, totalmente desvinculado dos efeitos de sentimentos (alívio-prazer), quando o dinheiro lhes é entregue no fim do mês. No caso do artesão, a condição de trabalho é diferente daquela do operário industrial. Ele não se sente alienado do produto final do seu trabalho, pois cada etapa do processo de criação e realização lhe pertence e então, a qualquer momento, ele produz um reforço condicionado positivo que é cumprir uma etapa - por mínima que seja - e ver o resultado gradual e preliminar satisfatório de sua criação. Neste sentido, fazer gera 
satisfação e, ao mesmo tempo, fortalece continuar fazendo. O ganho final pode ser generoso (no caso de ele ser um artista valorizado) ou modesto, mas o sentimento de prazer não se resume ao pagamento final. Provavelmente, o dia seguinte de trabalho de um operário é diferente do de um artesão.

\section{O QUE A HISTÓRIA DE CONTINGÊNCIAS TEM A VER COM REFORÇO LIVRE?}

Vamos imaginar que Fábio esteja andando por uma trilha. Seu olhar está sob controle das características do chão. Desvia-se de um buraco (comportamento selecionado por reforçamento negativo: evita alguma lesão), pula uma pedra (idem), corre com desenvoltura em um terreno plano, com superfície regular (comportamento selecionado por reforçamento positivo: ocorrem sensações corporais de prazer, despertadas pelas passadas largas e rápidas). Fábio vê no chão uma manga madura. Ele não produziu a queda dessa fruta na trilha, mas seu olhar produziu visão e localização dela. Se ela tiver função reforçadora para ele, então, terá a função de SD: pode pegá-la e, se quiser, saboreá-la. Trata-se de um exemplo de comportamento discriminativo: Fábio destacou a manga no chão empoeirado, pegou-a, saboreou-a. Comparemos isto com a situação de um sujeito experimental (por exemplo, um rato) privado de água na gaiola experimental, imóvel em um canto dela. A luz acende-se e ele avança em direção à barra. Ele precisa (é necessário e suficiente) pressionar essa barra e, assim, produzir uma gota de água; em seguida, sob controle do som do bebedouro, que tem funções de reforço positivo condicionado e de SD, ele pode se aproximar da gota e lambê-la. No primeiro exemplo, a pessoa poderia dizer para si mesma: "Que sorte! Adoro manga!" O rato não diria isso. Poderia dizer: "Sei como produzir uma gota de água! Basta a luz ser acesa e pressionar a barra..."

No exemplo da manga, Fábio, provavelmente, olhará ao seu redor em busca de outras mangas caídas, localizará a mangueira e, quem sabe, comportar-se-á para derrubar outras maduras, ainda na árvore. A que ficou no chão funcionou como uma gratificação, um presente, um reforço, enfim, e como um SD para emissão de várias classes de comportamentos: procurar outras mangas caídas, localizar a mangueira, procurar uma vara para derrubá-las, jogar pedras para que caiam, acumular algumas delas, levá-las para casa, distribuí-las para outras pessoas etc. Veja que um exemplo fortuito ocasionou a emissão de várias classes de respostas operantes como as citadas. Para tal ter ocorrido, supõe-se que Fábio tenha tido uma história de reforçamento que instalou comportamentos de tomar iniciativa, de ficar sob controle de consequências reforçadoras atrasadas ("À noite, no dia seguinte, poderei chupar outras mangas"), ter sensibilidade ao outro ("Vou dividir minhas mangas com o pessoal lá de casa!"), tolerância à frustração (carregar o peso das mangas pelo percurso), variabilidade comportamental (achar uma vara ou pedras e usá-las para derrubar as frutas, tirar a camiseta e com ela improvisar uma "sacola" para levar as mangas) etc. Ou seja, a pessoa, assim como o rato, fica sob controle dos eventos ambientais presentes em um determinado contexto e momento, em função de sua história de reforçamento. É no desenrolar de sua história de reforçamento que foram instalados e vêm sendo mantidos comportamentos e é a partir dela que o ambiente adquire determinadas características e funções: manga madura é amarela, é doce, é fruta de uma árvore, um leve toque no pedúnculo de uma fruta madura a faz cair etc. e é reforçadora, Sem uma história de reforçamento apropriada, tudo isso (e muitos outros componentes do episódio comportamental de achar uma manga no chão e tudo que se segue a esse encontro...) não ocorreria. A manga nem seria notada! De forma análoga, o rato responde à presença da luz, e só quando está acesa, pressiona a barra e se aproxima imediatamente da gota, porque a sua história de reforçamento instalou comportamentos e funções de estímulos apropriados à situação experimental. Um rato ingênuo comportar-se-ia de forma errática no mesmo ambiente físico.

Júnior é um garoto de seis anos cujos pais trabalham fora. Desde pequeno, passa o dia com Márcia uma empregada doméstica que cuidou de Ana, mãe de Júnior, e que veio morar com a família desde a gravidez de Ana. Passa o dia com Júnior, dividindo seu tempo com ele e com serviços domésticos. Júnior estuda à tarde. É a terceira escola que frequenta. Não se "adaptou" a qualquer outra nem a esta em que está; não se concentra nas atividades, tem sérias dificuldades com a alfabetização, não atende às instruções da professora, não se mantém sentado por muito tempo. Tem sempre colegas por perto, mas para bagunçar. Ele tem de ser o líder e se não fazem o que ele quer, grita, empurra... Fica difícil controlar seus comportamentos de "maus modos". Em casa, é uma criança difícil e seus pais dizem que as queixas da escola se repetem no ambiente familiar. A mãe assim o descreveu: "Quer tudo na mão, não toma iniciativa para nada, é desorganizado, desobediente, grita quando não o atendemos prontamente. Só fica tranquilo com a Márcia do lado. Até a dispensei dos trabalhos com a casa. Ela faz tudo que ele quer; mais que isso, ela adivinha o que ele quer e se antecipa." [...]

O tempo passa! Júnior é um jovem de 16 anos, e Ana, agora, procura um psicólogo para adolescentes: "Meu filho está afastado da escola. Fica em casa o dia todo na Internet, jogando por horas a fio... Diz que não vê razão para estudar. Ninguém fica rico estudando, diz. Canso de repetir que não seremos eternos, embora hoje nada lhe falte, o que será dele se não fizer alguma coisa de útil na vida? O que nos preocupa é que não tem limites. Sabe lutar sim, só pelo que ele quer, mas sempre exigindo, brigando com a gente. Parece que não tem bons sentimentos por nós. Deus me perdoe o julgamento: parece que não gosta nem de mim nem do pai dele. Mesmo dando tudo para ele, ainda falta algo. É ingrato e eu diria infeliz. Pior, sabe exigir, mas não sabe fazer. É completamente dependente de nós, em especial da Márcia, que parece uma santa... Tá mais velha... Não sei como aguenta fazer tudo para ele. E, sabe, nem agradece. É grosso também com ela.

Desde pequeno, por insistência de todas as escolas que frequentou, nós o levamos a vários psicólogos. Ficava uma, duas vezes e não queria ir mais. Hoje, nem 
pensar!... Uma psicóloga disse-nos uma vez que nosso menino precisava de limites. Ele não gostou dela e nós desistimos. Reconheço que somos muito ocupados. Eu e o Álvaro temos uma empresa que suga todo nosso tempo. Mas uma coisa eu garanto: "Não falta amor para o Júnior. Ele não tem do que se queixar. Tem de tudo. Mas para ele ainda é pouco!"”

Dá para concluir que Júnior não veria a manga no chão. Aliás, nem estaria andando por uma trilha. Talvez, só conheça fatias de manga colocadas para ele picadinhas em um prato. Nunca "notou" o que é uma manga. Se lhe perguntarem, talvez diga: "Uma fruta amarela com formato de pedacinhos irregulares que a gente encontra em cima do pratinho!" Nada além. Sua história de contingências de reforçamento instalou e vem mantendo padrões de comportamento de dependência do outro, baixíssima tolerância à frustração, reclama se os reforçamentos não são imediatos, apresenta baixa variabilidade comportamental (exceto para ter acesso ao que lhe é reforçador), é excessivamente sensorial, mostra completa indiferença ao outro, parece ser incapaz de amar quem quer que seja, tem déficit de repertório de cooperação, tem excesso de comportamentos agressivos, que se acentuam quando é contrariado ou de alguma forma frustrado, tem sentimentos de vazio existencial; vive para satisfazer desejos efêmeros.

Pode-se perguntar por que uma pessoa que recebe de outras praticamente tudo o que deseja, não as amaria? (Esse tema será retomado mais adiante).

Quando comparamos os comportamentos atuais de Fábio e Júnior, podemos concluir que seus repertórios comportamentais são completamente diferentes. Alguém poderia argumentar: "A diferença entre os dois ocorre, porque Fábio gosta de correr e Júnior não", e assim se contenta com sua "explicação". Quem assim fala atribui ao sentimento (Fábio "gosta" de correr) a "causa" que diferencia o comportamento de Fábio do de Júnior. Será sentimento causa de comportamento? Ainda mais, essa mesma pessoa poderia dizer que Fábio é mais desleixado do que Júnior com alimentação e, por isso, não se importa de pegar uma manga suja no chão e chupá-la. "Deve ter sido moleque de rua, que aprendeu a atirar pedras, usar estilingue... Júnior é mais cuidadoso com a limpeza daquilo que come e não tem as "malandragens" de quem passou a infância brincando na rua." As explicações que se referem, ainda que de maneira grosseira, a diferenças entre as histórias de reforçamento de Fábio e Júnior são mais apropriadas do que explicações atribuídas a sentimentos, uma vez que comportamentos, bem como sentimentos diferentes são ambos selecionados por exposição a diferentes contingências de reforçamento.

Assim, Fábio esteve durante seu desenvolvimento exposto a contingências de reforçamento nas quais comportamento produz consequências, as quais selecionam comportamentos. Além disso, os comportamentos e consequências ocorrem sob controle de estímulos condicionais: $\mathrm{SD}, \mathrm{S} \Delta, \mathrm{S}$ pré-aversivo etc. Por outro lado, Júnior teve uma história de contingências de acesso a coisas reforçadoras (que causam satisfação, prazer) mediadas, isto é, oferecidas por alguém que zela pelo seu conforto e bem-estar sensorial, e lhe dá o que o agrada, alheio à instalação e desenvolvimento de padrões de comportamentos necessários para tomar iniciativas, solucionar problemas, inovar comportamentos, ampliar reforçadores etc. Logo, Fábio aprendeu a correr e, ao fazer isso, sentir satisfação e bem-estar, ou seja, o comportamento (correr) e as sensações (agradáveis) são todos determinados por contingências de reforçamento. Junior, por sua vez, não aprendeu a correr e, por isso, correr lhe é custoso, estranho à sua rotina, portanto aversivo. Fábio aprendeu a responder de maneira ampla ao ambiente em que vive: discrimina o que lhe é reforçador e sabe como produzi-lo; discrimina o que lhe é aversivo e sabe como se esquivar ou fugir. Júnior discrimina o que há de bom e de perigoso no mundo por meio das verbalizações das pessoas que o cercam, ou seja, seus comportamentos são da classe dos intraverbais e não fruto de seu contato discriminativo com o mundo. Outra fonte de aprendizagem de Júnior são as sensações corporais imediatas que o levam a dizer o que é bom ou ruim para ele, ou seja, que se trata de uma aprendizagem tão somente sensorial. Isto o distancia de condições que usualmente ensinam as pessoas a responder seletivamente a contingências de reforçamento e não ao que, simplesmente, o agrada ou desagrada.

Em suma, os amplos déficits comportamentais de Júnior têm a ver com reforço livre. Podemos conceituar reforço livre como aquela situação na qual um evento, ou atividade, ou estímulo que tem função de reforço não é produzido por comportamentos específicos, mas é dado independentemente de qualquer contingência de reforçamento especificada previamente. Em um estágio inicial, podemos falar em relação funcional supersticiosa, no entanto toda e qualquer liberação de reforço é contígua a algum comportamento. Skinner (1948, 1999) demonstrou que pombos passaram a emitir respostas que eram reforçadas diferencialmente por consequências não contingentes, mas contíguas (supersticiosas). No caso humano, em um primeiro momento, oferecer, por exemplo, um suco a quem não o pediu pode instalar a resposta de pedir um suco quando condições de privação aumentarem o valor reforçador do suco e aumentarem a variabilidade comportamental, de tal forma que aparece a primeira ocorrência de um novo comportamento: "Quero suco!' A partir de então, a relação não é mais supersticiosa nem puramente contígua; passa a ser produzida por comportamento de pedir. A resposta de pedir torna-se forte e generaliza-se. A aquisição do comportamento de pedir ou perguntar (que pode ser uma classe dos comportamentos de pedir) traz benefícios para a pessoa, pois pode ampliar o acesso a condições ou a eventos reforçadores, ou evitar situações ou eventos aversivos. Há, no entanto, outras possibilidades: por exemplo, o doador pode não estar disposto a atender ao pedido.

Em circunstâncias adversas, aquele que foi exposto a reforço livre emite comportamentos, cujas funções comportamentais foram adquiridas na história de contingência dela. Ele, provavelmente, não aceitará a negação e, em vez de buscar outras formas de se comportar (apresentar variabilidade comportamental), que 
possam produzir o reforço, tenderá a escalar o comportamento de pedir para o de exigir, acompanhado de componentes emocionais, incluindo operantes com fenótipos agressivos. O comportamento agora é o de exigir de forma cada vez mais imperativa. Não se trata mais de comportamento selecionado por consequência reforçadora livre; a consequência é produzida pelos comportamentos indesejados. A condição aversiva gerada no provedor pelos comportamentos agressivos, ameaçadores, chantageadores é eliminada temporariamente pela aquiescência dele, que é assim reforçado negativamente. $\mathrm{O}$ ciclo repete-se e ocorre uma espiral perniciosa, que se caracteriza por pessoas dependentes de outras, improdutivas, exigentes porque os bens nunca as realizam plena e duradouramente; infelizes, agressivas, solitárias, incapazes de estabelecer vínculos afetivos genuínos, antiéticas, dominadoras. Por outro lado, o provedor sentese injustiçado, chantageado, refém das ameaças do outro, temeroso das consequências que poderá vir a causar, se não ceder: ser agredido, sentir-se responsável por autoagressões, inclusive com consequências extremas, como o suicídio. Triste o fim daquele que dá tudo, pois pode perder o essencial; triste o fim daquele que ganha tudo, pois nunca tem nada.

Segundo Skinner (1948, 1999), "Dizer que um reforço é contingente a uma resposta pode significar não mais do que ele se segue àquela resposta [...] condicionamento ocorre presumivelmente por causa da relação temporal apenas, expressa em termos da ordem e proximidade da resposta e do reforço." (p. 570)

\section{EVIDÊNCIA EXPERIMENTAL}

Segue a transcrição de alguns trechos do relato de Skinner (1948/1999).

“Um pombo é privado de alimento até $75 \%$ do seu peso quando tem livre acesso ao alimento. [...] Se um relógio é acoplado ao alimentador de forma a apresentar o alimento a intervalos regulares durante 5 segundos, sem nenhuma relação com qualquer comportamento do sujeito, ocorre condicionamento operante. Em seis de oito casos, as respostas resultantes foram tão claramente definidas que dois observadores puderam concordar perfeitamente na contagem de suas ocorrências. [...] Todas as respostas foram repetidas rapidamente entre reforçamentos tipicamente cinco ou seis vezes em 15 seg. Uma centena de fotos tiradas dois segundos após a retirada do alimentador mostraram padrões de comportamento razoavelmente uniformes: o pombo ficava na mesma localização na gaiola, perto do alimentador, em geral orientado em direção da parede onde estava o alimentador ou girando para um lado ou para outro. Uma centena de fotos tiradas após 10 segundos, por outro lado, mostraram o pássaro em várias localizações dentro da gaiola, respondendo a muitos diferentes aspectos do ambiente. Quanto mais rapidamente aparecer um segundo reforço, portanto, mais provável que a segunda resposta reforçada seja semelhante à primeira e também que ambas terão uma de poucas formas padronizadas. Um intervalo de 15 segundos [entre reforços] é um período muito eficaz para o nível de privação usado com pombos. Depois que uma resposta foi instalada, no entanto, o intervalo entre reforços pode ser aumentado. Num caso foi aumentado para 2 minutos e a alta frequência de respostas se manteve sem sinais de enfraquecimento. Em outro caso, muitas horas respondendo foram observadas com um intervalo de um minuto entre reforços. Neste último exemplo, ocorreram algumas mudanças na topografia da resposta, mas o padrão predominante produziu uma curva de respostas acumuladas com características produzidas por reforçamento intermitente de intervalo fixo: o pombo não respondia imediatamente, mas entre 10 a 20 segundos após o reforço aumentava a frequência de respostas até o próximo reforço. Foi possível obter uma curva de extinção quando o comedouro não foi mais acionado. Foram registradas mais de 10 mil respostas até o critério de poucas ou nenhuma resposta ser emitida em intervalos de 10 a 15 minutos. Quando o relógio foi religado e o comedouro voltou a funcionar, houve um recondicionamento da resposta prévia. Quando foi submetida a segundo processo de extinção e novo procedimento de recondicionamento, foi instalada uma nova resposta, e a resposta prévia não reapareceu (para evocá-la precisaria ser usado procedimento de modelagem).

O experimento, pode-se dizer, demonstrou um tipo de superstição. O pássaro se comportou como se houvesse uma relação causal entre seu comportamento e a apresentação do alimento, embora tal relação não existisse.

Não se pode dizer, porém, que o comportamento condicionado foi instalado sem qualquer contingência de alguma forma determinada previamente. Quando ajustamos o relógio para apresentar alimento a cada 15 segundos, estamos de fato baseando nosso reforçamento sobre um conjunto limitado de respostas, o qual ocorre, frequentemente, 15 segundos após o reforço. Quando uma resposta foi fortalecida (e para tal pode bastar um único reforço), a programação do relógio envolve uma contingência ainda mais precisa." (pp. 570574) 
Os dados produzidos pelo procedimento relatados por Skinner são equivalentes aos observados em seres humanos, respeitadas as diferentes complexidades do contexto experimental (essencialmente simples) e da vida cotidiana (extremamente complexa). Os padrões comportamentais mostram tendências comportamentais que se equivalem, como será visto.

\section{REFORÇAMENTO LIVRE EM SITUAÇÕES COTIDIANAS}

As três afirmações a seguir servirão de referências para a discussão do tema do artigo.

1. Não existe bem, não existe mal; existem contingências de reforçamento, que produzem (instalam, selecionam, mantêm) comportamentos que são classificados, arbitrariamente, pelo ambiente social em que a pessoa está inserida, como tendo funções de bom ou de mau, de desejado ou indesejado.

2. Consequências têm de ser produzidas por comportamento; assim, tornamo-nos sujeitos de nosso destino.

3. Consequências selecionam comportamentos; assim, tornamo-nos objeto de nosso destino.

\section{Aniversário \\ Fernando Pessoa}

\section{"No tempo em que festejavam o dia dos meus anos, Eu era feliz e ninguém estava morto. \\ Na casa antiga, até eu fazer anos era uma tradição de há séculos \\ E a alegria de todos, e a minha, estava certa como uma religião qualquer.}

No tempo em que festejavam o dia dos meus anos,

Eu tinha a grande saúde de não perceber coisa nenhuma,

De ser inteligente para entre a família, E de não ter as esperanças que os outros tinham por mim."

Reforçamento livre pode ser entendido como uma condição na qual uma pessoa ganha - sem emitir qualquer resposta pré-estabelecida como condição necessária e suficiente - itens, tais como um brinquedo, um doce ou sorvete, uma roupa etc., ou reforços generalizados, tais como dinheiro, atenção, carinho etc., ou acesso a atividades, tais como ir a um show, a uma balada, a uma viagem etc., que se mostraram, em determinadas situações, terem valor "gratificante" ou reforçador positivo para essa pessoa. O uso do termo "reforço", nestas condições, está autorizado (o próprio Skinner, (1948/1999) o usou) e é de uso geral, embora não atenda aos critérios de ao ser produzido por uma resposta específica pré-determinada nem fortalecer nem selecionar a resposta que o produziu. Assim, condições em que prevalecem apresentação de reforço livre são aquelas em que o reforço positivo é apresentado sem relação alguma de contingência de reforçamento (CR) sistemática; o reforço é contingente a qualquer ação não especificada da pessoa e não à emissão de determinados comportamentos pré-selecionados.

Há, no dia a dia, algumas condições principais por meio das quais a contiguidade entre uma resposta e o reforço pode ocorrer (o que pode ou não fortalecer a dada resposta): por mera contiguidade temporal acidental entre uma resposta e a "coisa reforçadora" (por exemplo, olhar para o chão e ver uma moeda); pela emissão de uma resposta não desejada, como um elo adicional em um encadeamento de respostas, a qual inesperadamente produz o reforço (por exemplo, ao tentar rebater a bola o tenista, sem querer, bate nela com o cabo da raquete e faz o ponto); pela mediação de uma pessoa que dá o reforço sem estar sob controle das contingências de reforçamento disponíveis e sem estar sob controle de que comportamento pode estar fortalecendo (indesejado ou desejado). Possivelmente, o papel de mediação exercido por pessoas seja a condição mais desastrosa para o desenvolvimento comportamental de um indivíduo. Neste artigo priorizaremos esta condição.

Assim, por exemplo, a mãe traz o suco favorito para o filho de quatro anos simplesmente porque "já faz muito tempo que Júnior não come nada..." Coincidentemente, ele está com o pé sujo apoiado no sofá e com o dedo na boca! A mãe somente lhe deu um reforço, sem atentar para qualquer relação de contingência entre os comportamentos do filho (quaisquer que tenham sido eles, desejados ou indesejados) e o estímulo ou evento que ocorreu, temporalmente, logo em seguida, em uma relação contígua...

Essa situação poderia acontecer de maneiras diferentes, a saber:

1. A mãe traz o suco para o Júnior e lhe diz:

- Júnior, trouxe um suco para você,

— Vamos lá: sente-se direito no sofá. Nada de pé com tênis nas almofadas.

— Isso! É assim que a mamãe gosta! Sentadinho como se deve.

— Tá docinho o suco?

Júnior começa a aprender que não deve sujar o sofá e se este procedimento de sua mãe for generalizado para outros contextos e comportamentos, ele aprenderá a generalizar a classe de comportamentos de tomar cuidado com a limpeza de coisas, objetos, ambientes etc. Assim, se encontrar o cobertor no chão do quarto, tenderá a colocálo sobre a cama; colocará, no lixinho, algumas folhas espalhadas pelo chão da cozinha, que entraram com o vento; quando adulto, manterá o interior do carro limpo etc.

Os próximos passos poderiam ser:

2. A mãe, distante de Júnior, pergunta:

— Júnior, você está com sede?

- Tô, mãe!

- O que você quer beber?

— Pode ser suco de laranja?

— Já levo para você...

A pergunta inicial da mãe controla o comportamento do Júnior de observar seu estado corporal. 
Para uma criança, esta questão pode ser necessária, mas a mãe deve estar atenta para, mais adiante, vir a instalar em Junior a iniciativa de se comportar sob controle do seu estado corporal.

Assim, a pergunta deve ser substituída por:

3. - Júnior, quando você estiver com sede pode me pedir um suco. dizer:

Mais tarde, quando Júnior pedir o suco, a mãe pode

4. - Você sabe onde está o suco, é só abrir a geladeira, ou

- Vamos até a cozinha e você me ajuda a preparar o suco.

Dessa forma, apresenta a situação e ensina Júnior a fazer o próprio suco (deve esvanecer sua ajuda, até o garoto emitir todos os elos da cadeia de fazer o suco e tomá-lo).

5. - Agora que você já sabe fazer suco de laranja sozinho; quando papai chegar, você prepara um para ele.

Além de ensinar a tomar iniciativa de fazer o suco quando estiver com sede, Júnior aprenderá também a emitir comportamentos que produzirão consequências naturais (tomar o suco); a mãe também o ensinará a se preocupar com o outro e a se comportar de modo a produzir reforços para outras pessoas (começa pelo pai, no exemplo), ou seja, generalizar a resposta aprendida que o beneficiará para outros contextos e pessoas.

Ao contrário da primeira situação, nas alternativas seguintes, a mãe aplica o reforçamento sob controle de contingências desejadas. Ela está ensinando o filho a emitir alguns elos de comportamentos que, mais tarde, poderão resultar em o filho preparar o suco sozinho. Não foi isto que ocorreu quando ela lhe deu o suco, porque "já faz muito tempo que...". A maneira inadvertida como a mãe deu o suco para Júnior, se não for modificada, de acordo com os exemplos, pode não ter final feliz. Agora Júnior, adolescente, é fonte de muitas preocupações da mãe, cujas principais queixas são:

- Não sei o que acontece com Júnior: não se mexe para nada nem para preparar o próprio prato de comida.

- Júnior não tem jeito mesmo! Pegou uma Coca na geladeira e, como sempre, foi beber no quarto. Não tem a menor consideração por mim. Larga o copo ao lado da cama, deixa restos de comida espalhados pelo chão...

- Outro dia achei um pedaço de bolo no meio dos lençóis. Tem mais: acostumou a se deitar sem trocar de roupa e, em outra noite, dormiu até com o tênis sujo de barro por cima das cobertas. Não aprendeu com exemplos aqui de casa... E não adianta falar.

- Essa apatia ele também apresenta na Escola. Tira notas baixas nas provas e não consegue se recuperar, porque nunca entrega as lições de casa nem os trabalhos.

- Acho que anda deprimido. Não tem amigos, não sai muito de casa é incapaz de ligar para algum colega de classe e combinar algum programa; está sempre desligado de tudo. De tudo não... ainda bem que se diverte com os joguinhos no computador!

Esses exemplos citados caracterizam a variedade de generalização de comportamentos de dependência, déficits importantes de repertório comportamental para tomar iniciativas, para apresentar variabilidade comportamental, descobrir novos reforçadores em interações sociais e em atividades lúdicas, indiferença ao que seu comportamento causa nos outros (não apenas em relação à mãe...) etc. Não devemos concluir que a mãe causou todas as dificuldades de Júnior porque um dia lhe deu o suco, enquanto estava deitado com os pés no sofá, mas raciocinar que o exemplo do suco foi um episódio que deve ter-se repetido em múltiplos contextos da vida dele, expandindo-se por muitas classes comportamentais e que durou por todo o seu desenvolvimento.

As duas citações a seguir, de Skinner (1975/1978), podem ajudar a compreender o que ocorreu com Júnior.

"Nós às vezes agimos para o bem dos outros. [...]. Nosso comportamento frequentemente tem consequências imprevisíveis que precisam ser levadas em conta." [Grifo nosso, adicionado]

"A espécie humana tem, presumivelmente, maior probabilidade de sobreviver se as pessoas em geral ajudarem umas às outras ou se forem naturalmente reforçadas por sinais de que agiram assim." (p.33)

Essas menções precisam ser contextualizadas e isso ocorrerá nas citações logo a seguir, mas circulam entre pessoas como regras transmitidas por tradições orais ou por instituições que apregoam, sem o necessário discernimento, a importância de fazer o bem. Talvez, Ana tenha como regra, que governa seus comportamentos, que "uma mãe deve dar tudo que lhe for possível para o filho", mas não está ciente de que uma pessoa com baixa autoconfiança, aquela que não se comporta para produzir reforços, pode morrer de fome em meio à abundância. $\mathrm{Ou}$ os pais argumentam: "Não quero que meu filho passe pelas privações e dificuldades pelas quais passei", ignorando que a maneira como vivem hoje, independentes, bem-sucedidos, emocionalmente e afetivamente estáveis, foi produzida exatamente pela vida difícil que tiveram e que selecionaram os comportamentos atuais que apresentam.

Skinner (1975/1978) retoma as duas citações e as contextualiza da seguinte forma:

"Na verdade podemos não estar ajudando de fato os outros quando fazemos coisas por elas. Isto é frequentemente o caso quando elas estão aprendendo a fazer coisas por elas mesmas. [...]. Ao dar muita ajuda, nós adiamos a aquisição de comportamento eficiente e perpetuarmos a necessidade de ajuda. [...]. Uma pessoa ajuda mais eficientemente outras pessoas quando, concomitantemente, para de ajudá-las.” (p. 35) 
"O fato de que o fortalecimento, no sentido de probabilidade de ocorrência, é uma propriedade importante do comportamento, só foi compreendida vagarosamente. Um ponto importante é que fortalecimento não é de forma alguma relacionado simplesmente com quantidade de reforçadores. Temos que considerar a possibilidade de que o fortalecimento do comportamento é mais importante que recebimento ou posse de bens." (p. 36)

São necessários alguns alertas. Assim, determinados padrões de comportamento, que podem ser prenúncio de graves problemas comportamentais no futuro, são considerados toleráveis e até engraçadinhos nas crianças. Frases como: "Veja como ela, assim pequenininha, já põe a mão na cintura e exige!", “Como nosso filho sabe argumentar!", "Vai ser um advogado de sucesso.", "Se lhe damos corda, passa horas falando...", "Às vezes rimos de sua maneira de se defender." "O melhor é ceder e por fim na conversa!"

Sob tais condições, a pessoa desenvolve padrões comportamentais e emocionais que podem ser considerados desejados a curto prazo (enquanto a pessoa é criança, por exemplo), mas que passam, em outros contextos ou com o avanço da idade, a ser considerados indesejados pelos membros da comunidade socioverbal próxima (família, escola etc.) e por pessoas que interagem com o indivíduo em ambiente de trabalho, em lugares públicos etc. Assim, dar presentes não contingentes para uma criança pode ser reforçador para o adulto, que se satisfaz com a reação de espanto do garoto, ou que acha criativa a reação da criança de desmontar incontinentemente o presente "para ver o que tem dentro..." A criança, agora adulta, exige roupas de grife, um carro surpreendente, cartão de crédito sem limite... simplesmente pelo fato de existir - sem se comportar para produzir o privilégio que deseja - indiferente às possibilidades financeiras dos pais ou aos desejos deles de lhe dar ou não o que quer... Agora o adulto não desmonta mais o brinquedo, mas detona o carro em um racha irresponsável pela sensação de "ver o que acontece!" O fato de que os pais passam a avaliar os comportamentos do jovem adulto como indesejados, bem como irresponsáveis as consequências, em geral danosas, que os comportamentos dele produzem, não influencia, necessariamente, a avaliação que o filho faz do seu próprio comportamento. Pelo contrário, na maioria das vezes, as "aventuras" pelas quais o jovem passa e os acidentes e brigas que provoca tornam-se assunto para animar as conversas com os amigos, por meio de narrativas teatrais, nas quais o vilão é o herói do espetáculo!

\section{Skinner (1975/1978):}

"Consequências inesperadas que decorrem quando se diz que ajudamos as pessoas podem ser muito mais sérias. Num ambiente em que coisas como alimento, abrigo, segurança são garantidas como direitos [são comuns frases como: - Não pedi para nascer!"; "O que vocês têm também me pertence!"...], elas tendem a servir menos como reforçadores. Aqueles que recebem ajudas generosas estão em posição daqueles que vivem em climas amenos ou possuem muitos bens. Não estão fortemente privados, nem aversivamente estimulados e, portanto, não estão sujeitos a certos tipos de reforço. Algumas formas importantes de comportamento não são nunca adquiridas ou, se foram adquiridas, não são apresentadas. Mas, tais pessoas não apenas não fazem nada pura e simplesmente; elas ficam sob controle de menos reforçadores [...] Doces se mantêm reforçadores para quem não tem fome; drogas e álcool têm efeitos reforçadores anômalos; reforço sexual sobrevive porque não deixamos saciação para outros; certos esquemas de reforçamento especiais (como aqueles que vigoram em máquinas de jogos de azar) tornam reforços fracos em eficientes; e tão somente o espetáculo de outras pessoas vivendo em condições extremas ou perigosamente, como se vê em filmes ou na TV, é reforçador." [Grifos nossos, adicionados] Pessoas, que têm pleno acesso a reforços livres, vivem enfadadas, desmotivadas e podem se expor a situações perigosas, que produzem sensações corporais eliciadas pelo perigo, desde que as ações de risco não exijam disciplina, nem treinamento (como por exemplo um salto eventual de paraquedas, passar a toda velocidade por um semáforo vermelho na madrugada etc. (pp. 36-37)

Eventualmente, a própria pessoa que vem emitindo comportamentos aversivos contra aquelas que as cercam pode tomar consciência de que seu repertório comportamental é fonte de dificuldades e sofrimentos e pode, até mesmo, lamentar que assim seja. Tomar consciência das próprias dificuldades comportamentais está sob controle de consequências aversivas, tais como, críticas dos seus pares a comportamentos, isolamento social, brigas com amigos e estranhos, rompimento de relacionamentos afetivos, dependência de álcool e outras drogas, perda do carro em uma colisão, ferimentos por envolvimento em brigas e em acidentes, prisões, cobranças de valores vultosos nos cartões de crédito, multas etc.).

Tomar consciência do excesso de comportamentos indesejados, por um lado, e do déficit de comportamentos desejados, por outro, não basta. É necessário que o indivíduo seja exposto a contingências de reforçamento que instalam e mantêm comportamentos de autocontrole, de tolerância à frustração, de responsabilidade, de cooperação, de respeito às leis, de submeter-se a regras do grupo social, da família, dos 
ambientes de estudo, de trabalho aos quais pertence e outros.

Todas essas classes de comportamentos têm em comum o atraso de acesso a reforçamentos positivos e o contato com condições aversivas (para ele), próprias da rotina a ser experimentada, ou seja, passar a conviver com duas condições que lhe são estranhas. Para pessoas se disporem a se engajar em mudanças tão dramáticas para elas, pode ser necessário introduzir controles aversivos, tais como reduzir acesso a dinheiro fácil, suspender o uso de cartões de crédito, reduzir posses que o tornam o centro das atenções (carros luxuosos, jantares em restaurantes caros, viagens cinematográficas etc.), limitar o acesso ao uso abusivo de álcool e drogas, disciplinar a rotina diária etc. Todos esses procedimentos são difíceis de ser implementados e envolvem, como forma de controle aversivo, basicamente perda de reforçadores positivos poderosos e imediatos, os quais, se forem aplicados isoladamente dentro de um programa de desenvolvimento de comportamentos desejados, aumentam a probabilidade de contracontrole em relação aos agentes das mudanças das condições permissivas (em geral os pais).

$\mathrm{O}$ controle dos excessos deve ser criteriosamente introduzido em conjunto com instalação de comportamentos desejados incompatíveis ou alternativos com os indesejados. Trata-se de mudanças radicais na rotina da pessoa e, mesmo com orientação profissional, a implementação das mudanças ambientais é muito complicada. Uma primeira e mais evidente razão é que reforços imediatos e poderosos devem ser substituídos por reforços menos intensos, a maioria dos quais produzem mudanças perceptíveis somente a médio e longo prazo, ou seja, as mudanças são aversivas. Podemos concluir, então, que mesmo que a pessoa, no início das mudanças, esteja ciente e de acordo que elas se fazem necessárias, as contingências de reforçamento que a tornam consciente não terão o poder de transformar "consciência" em comportamentos.

Depara-se, então, com a realidade de que todo o processo de desligamento dos reforços livres e dos sentimentos de prazer associados a eles é muito abrangente e complexo. Adicionalmente, as mudanças devem ser - caso ocorram - no ambiente em que o indivíduo tem vivido, exposto aos mesmos controles de estímulos poderosos que vinham atuando, agora contrastadas com novos controles de estímulos, os quais ainda têm pequena força para evocar comportamentos novos que devem competir com os anteriores. Há de ser lembrado ainda que o repertório comportamental, mesmo que indesejado por um grupo de pessoas do convívio do indivíduo, produz reforços sociais para ele provindos de nichos particulares de "amigos", que têm ganhos com o poder que a pessoa ainda tem (programas sociais, acesso as bebidas e drogas etc.).

"Poder" é comportamento que produz reforços intensos, cria dependência psíquica e orgânica, mas, acima de tudo, o poder para ser mantido, exige que o "poderoso" disponibilize os reforços para outras pessoas que o cercam. Elas, necessariamente, precisam reforçá-lo de forma intensa para continuarem tendo acesso ao que ele lhes proporciona. Fica fácil entender que os reforços sociais do grupo são mais influentes que os reforços sociais vindos da família. Convém lembrar, mais uma vez, que os reforços poderosos não são produzidos por comportamentos da pessoa, o que nos permite concluir, então, que ela é dependente de outrem e, como tal, vulnerável. A pessoa não vive bem, vive para os bens. Como consequência, vive alienada e distante dos reforços e da maneira de produzi-los (por reforçamento), próprios do Homo Sapiens: fazer para ter. Neste aspecto, a pessoa desafia o sentido da Vida - que foi distorcido pela cultura, de modo amplo, e pelo núcleo familiar no qual vive de maneira particular - e deixa de se comportar, sistematicamente, sob controle de contingências de reforçamento que selecionaram comportamentos e, como decorrência, os membros da espécie humana. Assim, a vida é-lhe vazia, porque faltam os sentimentos derivados de produzir reforços positivos ou de se safar de eventos aversivos; ilude-se com sensações agradáveis transitórias e não consegue se bastar com aquilo que é bom, mas que rapidamente se esvai; sente-se desamparada diante de mudanças inesperadas na sua rotina (perda de familiares fornecedores de privilégios, falência financeira de fontes produtoras de riqueza etc.), uma vez que não possui variabilidade comportamental; o presente torna-se o que nunca soube que existia: um futuro que começa nas próximas horas sem provisões e sem esconderijos.

Skinner (1986/1987) interpretou aspectos da evolução do Homem da seguinte forma:

"Quando o aparato vocal do Homo Sapiens ficou sob controle operante, a linguagem nasceu e com ela uma evolução muito mais rápida de práticas culturais. Estas práticas trouxeram ganhos extraordinários, os quais podem ser vistos mais claramente na fluidez, saúde, bem-estar e liberdade do mundo Ocidental, mas o mundo não era mais o mundo em que as espécies evoluíram. O homem ancestral não trabalhava para os outros, nem pagava para os outros trabalharem para ele. Ele não agia simplesmente de acordo com o que lhe aconselhavam a fazer (ele podia imitar outros, mas apenas em ambientes grosseiramente semelhantes). Ele não observava regras nem obedecia a leis. Ele não olhava fotos, nem ouvia músicas, nem jogava [em cassinos] (jogava a sua vida e os riscos eram o de perdê-la) [...] Reforçar significa praticamente fortalecer, e quando as consequências fortalecedoras do comportamento foram sacrificadas em favor de agradar as pessoas, o comportamento simplesmente se enfraqueceu. Esta não é uma conclusão animadora, e é difícil deixar claro o que ela significa.” (p. 26)

Será que se está pressupondo que as pessoas felizes são aquelas que trabalham? Não serão as pessoas que curtem a vida, que ganham ou obtêm o que que lhes é 
importante, sem se preocupar em produzi-las, aquelas que vivem mais felizes? Tal questionamento é completamente equivocado, no entanto não é objetivo deste texto analisálo. Lembramos que as respostas a estas perguntas estão no Walden Two (Skinner, 1948/1976)

\section{Skinner (1975/1978):}

“A 'boa vida' não é um mundo no qual as pessoas têm o que elas precisam; é aquele em que as coisas de que precisam fazem parte como reforços das contingências eficientes.” (p. 44)

Ser parte de um mundo que privilegia o prazer produzido por bens, em detrimento do fortalecimento de comportamentos que produzem tais bens, não é escolha. As pessoas são vítimas das contingências de reforçamento que lhes foram impostas e não têm comportamentos alternativos para mudar sua condição. Não são felizes; sofrem! Equivalem a pessoas que se tornaram dependentes de drogas ilícitas. Tais compostos químicos não existiam disponíveis no ambiente em que o Homo Sapiens foi selecionado. Skinner classifica-os como reforçadores anômalos, que tendo sido introduzidos no ambiente humano por práticas culturais, têm efeitos reforçadores quando usadas (sensações prazerosas), e efeitos aversivos quando lhes é vedado acesso a elas (síndrome de abstinência). O reforço livre é uma possibilidade no mundo natural; tornou-se uma certeza no mundo dito civilizado pelas práticas culturais. A cultura não descobriu uma maneira de ter a "boa vida", mas a de iludir que ela pode existir.

Skinner (1975/1978) afirmou:

"O destino daquelas pessoas, cujos comportamentos não são frequentemente reforçados [não produzem reforços pelos comportamentos que emitem] — porque outros fazem as coisas para eles, ou porque não aprenderam a fazer as coisas por si mesmas, ou porque lhes são dadas as coisas que, de outra forma, reforçariam seus comportamentos - é suficientemente familiar. [...] Na verdade elas sofrem de um mundo no qual o comportamento delas não é reforçado positivamente." (p. 38)

O tempo passa, as circunstâncias mudam. A pessoa pode ficar alijada dos reforços porque o grupo social que mantinha seu repertório comportamental se esvaneceu e não há fontes alternativas de reforços; os déficits e excessos comportamentais excluem a pessoa de qualquer contexto social outro, diferente daquele que se perdeu. Não há mais esperança; instala-se o desespero, a falta de perspectiva e a dependência do outro se escancara, uma vez que já não está mais disponível o alguém a quem se agarrar. O quadro psicológico mais provável é a depressão.

\section{“Quando vim a ter esperanças, já não sabia ter esperanças.}

Quando vim a olhar para a vida, perdera o sentido da vida.

Sim, o que fui de suposto a mim mesmo,

O que fui de coração e parentesco.

O que fui de serões de meia-província,

$O$ que fui de amarem-me e eu ser menino, O que fui - ai, meu Deus!, o que só hoje sei que fui... A que distância!...

(Nem o acho...)

Aqui, cabe introduzir uma reflexão mais abrangente: as preocupações que foram apresentadas em relação à pessoa não se restringem a ela. A cultura é produto de pessoas, portanto os alarmantes problemas que o mundo vive hoje (poluição ambiental, conflitos armados, ascensão de políticos populistas, manutenção de governos ditatoriais, escassez de itens básicos para sobrevivência, analfabetismo, dinheiro multiplicando dinheiro e não bens, fé ignorante a serviço do poder etc.) são produtos de comportamentos de Homens. A cultura se fortalece com comportamentos de Seres Humanos que sobrevivem quando a cultura seleciona comportamentos compatíveis com a sobrevivência do grupo. Não há vida boa; há Vida, que se define pelas leis naturais que a regem e que não podem ser burladas impunemente.

Skinner $(1975,1987)$ :

"Tem sido fácil colocar possessão [ter porque foi dado] à frente de aquisição [ter porque se comportou para ter] e ignorar a importância de fortalecer o comportamento e sua relação com contingências de reforçamento. Na sala de aula, hospital, fábrica, prisão, lar, e no mundo em geral, o fato obvio é que algumas das boas coisas estão em falta. Estamos apenas começando a ver que a mera escassez não é o que está causando problema e que as pessoas não serão, necessariamente, ajudadas aumentando o suprimento.” (p. 45)

A condição de que alguém dá coisas para o outro é apenas uma das possibilidades em que opera o reforço livre. Não é necessário viver em um ambiente de abundantes bens materiais para manejar de forma perigosa os reforços positivos disponíveis. Assim, uma família que cerceia as iniciativas da criança para fazer coisas, (e que, dessa maneira, limita comportamentos que podem produzir reforços naturais), que usa excessivos elogios e aprovações - desconectados de relações de contingências de reforçamento construtivas - também faz mal. Assim, quando "os de casa" valorizam capacidades do garoto: "Ele é muito inteligente, entende toda a trama que se desenvolve na novela...", mas o menino não faz a lição de casa sozinho, precisa de alguém ao seu lado para levá-lo à razoável compreensão de um texto escolar, não estão, na melhor das hipóteses, levando-o a usar suas capacidades.

Os pais podem valorizar demasiadamente o discernimento que o filho tem - assim eles pensam - da 
realidade social. Podem, desta maneira, valorizar comportamentos críticos do filho, com a pretensão de que se destaque na escola e no mundo em geral, como uma pessoa diferenciada pela sua perspicácia, quando na verdade podem estar selecionando comportamentos nem tão brilhantes assim, mas que produzem isolamento social, porque o jovem passa a ser avaliado como uma pessoa "do contra", incapaz de flexibilizar seus comportamentos, de modo a contribuir com o seu grupo com análises ponderadas. Embora, eventualmente, os comentários do filho mereçam reconhecimento, os pais mantêm, como consequência, o padrão comportamental de criticar, sem o levarem a ficar sob controle discriminativo das condições, sob as quais os comentários são pertinentes e a dificuldade de instalar comportamentos diferenciados, próprios em cada contexto, podem levá-los a manter no filho várias classes de padrões comportamentais aversivos para os demais. Os pais precisam entender que o que tanto almejam para o filho, uma brilhante inserção no mundo acadêmico e profissional, pode estar levando-o a um isolamento social, que pode atrapalhar seus sonhos, ou serem alertados de que isso, ainda pior, pode dificultar a vida do próprio filho.

Saber deve incluir saber conviver. A "genialidade" despertada por elogios excessivos, não contingentes sobre desempenho, pode inibir os genuínos comportamentos de competência, e ainda mais, neste caso, pode resultar em menos. A dificuldade para o filho integrar-se no mundo social pode ser corrigida, adotandose procedimento de reforçamento diferencial para o filho discriminar as funções que seus comportamentos têm sobre o outro. A frase de Fernando Pessoa - "de ser inteligente para entre a família" - sintetiza a competência supersticiosa mantida entre os muros dos seus.

Não basta aprender apenas a criticar, mas também a valorizar o outro, discernir que se faz necessária a tolerância em relação às diferenças. Se os pais não estão atentos a este ponto, serão eles, no futuro, também vítimas de críticas generalizadas do filho, que se tornará crítico dos comportamentos dos próprios pais e passará a se opor a eles. Virá a ser uma pessoa intolerante com aqueles que o cercam e a se esmerar em apontar as falhas do outro, sem o devido equilíbrio entre comentários construtivos e depreciativos. Passará a viver isoladamente, sofrendo reveses de rejeição, incapacitado para estabelecer relações afetivas genuínas e duradouras. E o mais preocupante: estará convicto de que está certo em agir assim, pois foi o único repertório de comportamentos de interação social que aprendeu! Similarmente, em um outro exemplo, os pais comentam orgulhosos que o filho de 7 anos já conseguiu desmontar o aparelho de som que acabou de ganhar no seu aniversário..." "Ele é muito curioso e habilidoso; desmontou o 'som'... tem vocação para ser engenheiro... se interessa pelo funcionamento das coisas". Mas quanto às perguntas: "E o que ele fez em seguida?... Montou o equipamento novamente? $\mathrm{O}$ aparelho voltou a funcionar?", as respostas provavelmente serão: "É muito criança para isso. Está tudo lá em um canto do quarto. Temos de levar para consertar ..." Tais exemplos têm em comum que a descrição de capacidades e habilidades do filho não corresponde à emissão de comportamentos que completam um necessário e essencial encadeamento de respostas, o qual se resume em fazer o necessário, até que os comportamentos emitidos produzam reforço natural, sem necessidade da intermediação de outra pessoa.

Existe uma prática cultural que consiste em guiar o comportamento por meio de regras. A função mais evidente de uma regra é colocar o comportamento da pessoa sob controle da descrição de contingências de reforçamento. Tais descrições podem ser apuradas e testadas (por exemplo, as leis formuladas pela Ciência Natural) e, nesse sentido, proteger e orientar as pessoas como melhor proceder. Por outro lado, a regra pode advir de tradições orais de determinada cultura ou grupo familiar e não se apoiarem em evidências empíricas confiáveis. Assim, por exemplo, um dito popular que tem função de uma regra, como "roupa suja se lava em casa", pode levar a pessoa a se privar da riqueza de contatos francos com outras pessoas, até mesmo com profissionais, tais como médicos, psicólogos, em situações de real necessidade, porque procurar ajuda e falar das ocorrências cotidianas de sua vida familiar, que lhe são aversivas, estão vetadas pela regra. As asserções contidas nas regras, dependendo de sua precisão para descrever contingência, podem ser libertadoras ou alienantes. O que leva uma pessoa a ficar sob controle de uma regra podem ser as ocorrências das consequências previstas por ela, quando a pessoa se comporta sob controle dela (fala-se em "tatear" as consequências) ou pelas consequências diferenciadas, vindas da pessoa que enunciou a regra, ou seja, o agente do controle comportamental do outro reforça positivamente quem se comporta de acordo com a regra ou pune quem se opõe a fazê-lo (fala-se em aquiescência à agencia controladora). Neste caso, o comportamento supersticioso caracteriza-se pela submissão ao controle coercitivo, quer seja ele com fenótipo de reforçamento positivo ou aversivo, quer se resuma na crença de que seus comportamentos são adequados porque são diferencialmente selecionados por alguém preocupado em mantê-lo na condição de líder. O comportamento que é fortalecido não beneficia a própria pessoa nem seu grupo, mas as crenças do controlador. A fé no que pode não existir leva à alienação da realidade do grupo maior que o cerca e à adesão, que pode lhe ser perniciosa, do grupo menor que o catequisa.

A grande limitação do comportamento governado por regras que é mantido por aquiescência é que seguir regras pode enfraquecer os comportamentos da pessoa, quando esta estiver distante da agência que define como consequência o seguimento dessa regra. Assim, uma mãe dominadora, superprotetora do seu filho, pode elaborar uma regra que ela aplica desde a infância dele: "Há muitos perigos fora de casa; há tempo para você aprender tudo que existe lá!". A regra é conveniente para ela às custas de privar que o filho tenha um desenvolvimento mais natural dentro do ambiente social dele. Assim, toda vez que o filho, agora jovem, quiser fazer programas com seus colegas de escola (assistir a um show, ir a uma balada, descer com a turma para a praia, participar de um churrasco na casa de um deles etc.) ela repete a mesma 
regra. A mãe pode influenciar a concordância do filho desde pequeno por meio de duas estratégias: tornando o mundo fora de casa assustador, fazendo com que ele desenvolva fobias que o levarão a evitar o mundo que seus amigos tanto apreciam, com o consequente déficit do repertório de comportamentos próprios de suas fases de desenvolvimento: passa a ter medo de dirigir, de conviver com grupos de colegas que têm hábitos diferentes dos seus, de viajar sem os pais, de se envolver com uma garota etc., de tal maneira que "preferirá" ficar ao lado dos pais. A segunda estratégia é valorizar excessivamente a vida do lar: "Somos uma família unida"; "O que nos mantém juntos é nosso amor de um para o outro" etc. Quando o filho precisar emitir comportamentos próprios da idade adulta (por exemplo, ter um relacionamento afetivo e sexual, terá dificuldades para fazer sexo e conquistar uma companheira; quando no trabalho tiver de se ausentar por motivo de uma viagem profissional, sentirá muita ansiedade para enfrentar tudo que for novo e assim terá muitas outras dificuldades e limitações).

O déficit generalizado de comportamentos não será simplesmente superado porque a frase materna "haverá tempo para você aprender..." já passou! Além disso, a agência controladora dos comportamentos de seguir regras (a mãe) já não tem mais atualidade no mundo em que o filho agora vive, bem como, no novo mundo, as regras já são outras e se tornaram excessivamente complexas (pois falta-lhe repertório comportamental) para serem seguidas e, finalmente, a agência de controle (por exemplo, um gestor empresarial) poderá ser implacável com as inaptidões profissionais de seu funcionário, isto se ele conseguir ser admitido em um emprego! Sua vida pessoal tenderá a ser solitária e a profissional frustrante, pobres em reforços e rica em condições aversivas para ele.

A comunidade socioverbal não tem consciência de que foi ela que instalou e mantém os padrões comportamentais agora avaliados como indesejados e, como tal, insiste em apontar aquele, cujo comportamento ela critica e lamenta, por um lado, como indolente, acomodado, fraco, desmotivado, sem iniciativa, deprimido etc. ou, por outro, como agressivo, ingrato, arrogante, irresponsável, frio, calculista, manipulador etc. Seu próprio produto é culpado de ser um mau produto! De outra forma, a própria pessoa, envolta no esquema de reforçamento livre, não avalia, necessariamente, que esteja vivendo de uma maneira que lhe possa ser danosa. Tal alienação do indivíduo caracteriza-se pela permanência na condição comportamental e emocional em que se encontra, alheio às consequências adversas que virão a médio e longo prazo. Essa alienação não é uma escolha em relação a um estilo de vida, mas fruto das CR em operação, cujas funções imediatas lhe convêm. As consequências adversas só aparecerão mais tarde e, como tal, são ainda desconhecidas naquele momento. Mesmo que o indivíduo venha a ser alertado sobre a possibilidade de danos futuros, tais previsões são ignoradas. As principais características comportamentais, emocionais e afetivas, que se instalam e se mantêm no indivíduo exposto a reforços livres de modo frequente, podem ser assim categorizadas:

\section{A. Comportamentos 1948/1959) \\ supersticiosos \\ (Skinner,}

Os reforços livres ocorrem em contiguidade com determinadas classes de comportamento. Alguns itens dessas classes fortalecem-se supersticiosamente e ocorrem com maior frequência. Assim, há várias atividades dos filhos que os pais consideram indesejáveis, mas que são mantidas por consequências naturais. Assim, manter-se jogando por horas a fio pela Internet, alheio ao mundo ao seu redor, em horários estranhos ao das atividades de pessoas em geral, é exemplo claro. Os pais, então, podem definir consequências para os comportamentos do filho na enganosa tentativa de evocar comportamentos incompatíveis ou alternativos ao padrão persistente de jogar - com frases tais como: "Você está há muito tempo dentro de casa; por que não sai para tomar sol?"; "Por que não procura algum amigo?" e, adicionalmente, pode levarlhe uma barra de chocolate com um comentário carinhoso: "Para adoçar sua madrugada..." Esperam, dessa forma, que tais frases motivem o filho a fazer algo diferente (sem conhecimento conceitual, eles têm a expectativa de que essas frases funcionem como SD na forma de instruções, que evoquem os comportamentos nelas explicitados), no entanto elas provavelmente terão a função, inesperada por eles, de aprovação dos comportamentos do filho, que pode interpretar a intervenção parental como aprovação de seu esforço continuado... no jogo. Ele pode pensar: "Meus pais são compreensivos, entendem que minha vocação é me tornar um e-gamer. Às vezes, pode ser até pior, pois há pais que, em condições como essas, parecem acreditar na improvável generalização que fazem de que um comportamento excessivo (jogar por horas em horários impróprias) pode ser incompatível com os comportamentos desejados por eles no futuro do filho. Poderá se generalizar para um outro contexto futuro em que, o excessivo poderia ser desejável: "Nosso filho é tão talentoso. Ele passa horas no seu vídeo game... Noto que sua concentração e persistência na atividade são fantásticas... Fico pensando que, quando se formar médico, vai ser como aqueles cirurgiões que ficam 10, 12 horas em uma sala de cirurgia... Nunca entendi como eles conseguem, mas começo a ter uma ideia de como deve ter sido a infância deles..." Os familiares não estão conscientes dos danos comportamentais que seus procedimentos podem produzir. $\mathrm{Na}$ realidade, manter-se por longos períodos ao computador, jogando, pode ser incompatível com estudar e vir a fazer um curso de medicina, pois esses comentários podem instalar "crenças" supersticiosas no filho, tais como: "Vou ser cirurgião quando crescer; meus pais sabem das minhas capacidades..." Pensar assim não é o problema; não adquirir o repertório comportamental para tornar realidade pensamentos como esse é o problema!

\section{"O tempo em que festejavam o dia dos meus anos! O que eu sou hoje é como a umidade no corredor do fim da casa, Pondo grelado nas paredes...}




\section{O que eu sou hoje (e a casa dos que me amaram treme através das minhas lágrimas), \\ O que eu sou hoje é terem vendido a casa, É terem morrido todos,}

É estar eu sobrevivente a mim mesmo como um fósforo frio..."

Tais interações dos pais (e de pessoas significativas para o desenvolvimento do garoto) - quer eles o queiram, ou não - restringem-se ao que são consequências socioafetivas verbais, não contingentes a comportamentos desejados e que não adquirem funções de estímulo discriminativo, evocador de comportamentos de se engajar em outras atividades desejadas e necessárias. O que eles dizem não influencia o filho a se comportar como eles desejam; o que eles fazem, em geral, é incompatível com o que dizem, mas tem poderosa influência sobre os padrões comportamentais que o filho virá a apresentar. Ele não vai sair do quarto, não vai se engajar em atividades de lazer fora de seu reduto; isolado, contenta-se com o isolamento; seus "amigos" são os parceiros de e-jogos; as atividades esportivas ao ar livre lhe são estranhas. O filho permanece fazendo mais do mesmo. A pobreza de variabilidade comportamental não cria possibilidades para os pais reforçarem diferencialmente novos padrões comportamentais, e o filho não se comporta de maneira a produzir quaisquer reforços. As palavras dos pais terão efeitos nulos... eles continuarão dizendo as mesmas coisas, o filho continuará ignorando as frases deles, os pais continuarão fazendo pelo filho, alheios à função que estarão fortalecendo nos comportamentos deles. A citação que se segue integra-se de maneira apropriada ao que se está discutindo. "Quando se dá às pessoas o que necessitam, sem importar o que elas estão fazendo, elas permanecem inativas." (Skinner, 1969, p. 37), e ampliando o mesmo conceito para um nível mais abrangente, Skinner (1985/1987, p. 42) escreveu: “Ajudar quem não pode ajudar a si mesmo fortalece uma cultura, mas ajudar quem pode ajudar a si mesmo a destrói."

Assim, enquanto a família mantém as condições de liberar reforços livres, sem se questionar e sem exigir mudanças no filho, este se justifica com frases e pensamentos (comportamentos supersticiosos), tais como "Eu mereço o que recebo"; "Meus pais fazem assim porque querem"; "Estou vivendo muito bem, para que me preocupar?" etc. Se, no entanto, a família tenta mudar as condições, então surgem outros padrões comportamentais, tais como. "Eles têm obrigação de me dar aquilo que quero ou a que tenho direito"; "É obrigação das pessoas fazerem isso por mim"; "Não entendo por que minha mãe fica pegando no meu pé"; "Meus pais mudaram..."; "São incoerentes: ora me dizem uma coisa, ora dizem outra..."; "Nem meus pais se entendem..."; "Estou cansado de ouvir suas filosofias..." etc. Pensamentos ou autorregras, dados como exemplos, distorcem a natureza das relações interpessoais e se estabelece uma inversão de controle: agora o filho exige dos pais e estes sucumbem às imposições do filho, ameaçados pelo que pode ocorrer de mal com ele "por causa" de suas incipientes recusas de atender às exigências que, afinal, tendem a ser atendidas. $\mathrm{Se}$, no entanto, os pais insistirem em mudar seus comportamentos, os conflitos acentuam-se, pois o filho não tem comportamentos (não foram instalados) para oferecer aos pais e só lhe resta resistir.

Está é uma boa pista para os psicoterapeutas: as mudanças devem ser mediadas por ele e conduzidas na direção de introduzir alterações graduais não só nos comportamentos do filho, como também nos dos pais. Se concordarem em estabelecer limites àquilo que vêm dando para o filho, a distribuição dos bens deve ser manejada gradualmente: devem ser dados contingentes a comportamentos com exigências aumentadas lentamente. Para uma pessoa querer mudar, é necessário introduzir contingências reforçadoras positivas que produzam tal desejo e assim ocorrerá o sucesso na emissão do comportamento, quando se planeja com sensibilidade o ritmo de aumento das exigências. Tal estratégia é um dos vários espaços que precisam ser dados concomitantemente. A literatura da análise experimental sobre o comportamento de escolha oferece riqueza de informações sobre processos que interessam nas condições problemáticas das quais estamos falando.

A história de contingência do filho $\mathrm{e}$ as contingências atualmente em vigor constroem outras classes de comportamentos e crenças supersticiosas sobre suas capacidades: "Eu posso, eu sou capaz... eu só não faço (aquilo que se exige dele), porque não quero". Equivale a pensar que "assim que eu quiser, farei um curso universitário"; "assim que eu quiser, começarei a trabalhar com um bom salário"; "assim que eu quiser, pararei de beber e de usar drogas". "Não quero agora, porque estou 'sem energia"”; "Não faço agora, porque meus pais são injustos. Eles podem me manter da maneira que vivo; não entendo por que eu preciso mudar..." Desta forma, o resultado de todo o processo de acesso a reforços livres terá de ser revisto com a pessoa com déficits importantes de comportamentos, mas ela precisa se tornar ciente de suas próprias limitações, por meio de diferentes formas; ela tem de entrar em contato sistemático com um grupo preocupado em fortalecer comportamentos e em minimizar acesso a consequências que satisfazem prazeres. Se não expandir seu universo, ora superlimitado, vai se manter dependente desse ambiente social restrito onde vive, sem reconhecer tal dependência, uma vez que o comportamento de exigir aquilo que supõe ser seu direito é um comportamento de esquiva bem-sucedido; não testa, no cotidiano, a ausência de comportamentos para produzir - ele próprio - os reforços. Para pessoas nessas condições, ganhar não equivale a produzir, desdenhando uma evidência fundamental; são seus comportamentos de exigir de uma comunidade social restrita que produzem aquilo que quer. Não está ciente, no entanto, de que tais comportamentos não terão a mesma função em um ambiente social diferente, no qual seu poder de controle sobre as pessoas pode ser nulo!

A necessária discriminação entre o grupo social, sobre o qual a pessoa tem controle e outros grupos sociais, sobre os quais tal controle não acontece, não se estabelece. 
Ocorre uma generalização que, quando for testada, mostrar-se-á irreal, qual seja: "Todas as pessoas (ou a maioria delas) me servirão!"; "O simples fato de eu existir e ter desejos garante a mim o acesso ao que quero...". Tal generalização, que se expõe como uma autorregra construída a partir de pressupostos ou dados insustentáveis na realidade (logo, uma autorregra insensata), é mais um exemplo de comportamento supersticioso. Skinner (1986/1987) expôs a construção de autorregras (embora, neste texto citado, ele não as denomine assim) da seguinte forma:
"Alguns dos conselhos que seguimos são do tipo que damos para nós mesmos. Nós examinamos um conjunto de contingências e formulamos uma regra ou plano [autorregras]. Quando seguimos a regra ou plano, dizemos que agimos racionalmente, no sentido de que agimos por uma razão que podemos nomear. Mas, a menos que sejamos muito bons para analisar contingências, muitas das consequências que previmos não ocorrerão nunca. Raramente somos tão fortemente inclinados a nos comportarmos racionalmente como somos inclinados a agir de acordo com consequências experienciadas." (p. 22)

Eventualmente, a pessoa entra em confronto com outros grupos sociais, nos quais os indivíduos não se curvam ao controle egoísta que foi fortalecido no seio familiar. Ocorre, então, uma discriminação em relação às consequências de seus comportamentos: "Às vezes posso; às vezes não posso!" Mas mesmo esta condição social que poderia estabelecer um comportamento discriminativo, resumido na frase: "Com minha família, sou poderoso, dão tudo aquilo que quero; no meu trabalho, nada me é dado; tenho de me comportar das formas esperadas, de acordo com as normas do contexto profissional, para produzir o que devo", não é suficiente para instalar a discriminação. A pessoa tende a fazer julgamentos depreciativos sobre aqueles que não se deixam controlar pelos caprichos e exigências dela: "Eles não gostam de mim, porque tenho mais que eles"; "Eles são de outra tribo, por isso me excluem"; "Não nasci para ser empregado..."; "As pessoas são preconceituosas..."; "Esta empresa escraviza seus funcionários..." etc. A pessoa que assim pensa e assim age comporta-se de forma sensorial no ambiente social em que vive: "É bom o que é bom para mim; é mau o que não é bom para mim!" As CR que regulam as interações sociais lhe são indiferentes; seus comportamentos são governados por regras e autorregras supersticiosas e não são influenciados pelas consequências sociais que produzem. Ter prevalece sobre ser. A citação de Skinner a seguir aponta para os malefícios de priorizar o bom: "Nem a felicidade, nem a sobrevivência do grupo dependem de satisfação derivada de ter coisas." (Skinner, 1975/1978, p. 47).

A questão que deveria ser feita diz respeito aos sentimentos de uma pessoa nessas condições. Quando o bem-estar de alguém depende diretamente dos comportamentos daqueles que a cercam, a resposta mais provável é que ela não pode se sentir bem, pois se comporta o tempo todo esquivando-se, fugindo do perigo de perder as pessoas que lhe dão abrigo: a satisfação de ganhar é fugaz; a ansiedade por perder é perene. Assim, Skinner (1969) dispôs:

\begin{abstract}
"Os homens são felizes em um meio ambiente no qual o comportamento ativo, produtivo e criativo é reforçado de forma eficiente. $\mathrm{O}$ problema, tanto com a sociedade afluente, como com a paternalista é que os reforços não são contingentes ao comportamento. Homens que não são reforçados por fazer alguma coisa fazem pouco ou nada, [...] [O reforço livre] pode atender a satisfação de necessidades, mas suscita outros problemas. Somente quando pararmos de usar reforços para aliviar necessidades é que poderemos começar a utilizá-los para 'satisfazer a natureza humana' num sentido mais importante.” (p. 64)
\end{abstract}

\section{B. Sentimentos e comportamentos de autoconfiança e de autoestima distorcidos.}

Autoconfiança e autoestima são comportamentos instalados e mantidos por CR específicas (Guilhardi, 2002), mas podem ser selecionados de forma supersticiosa, quando a pessoa tem acesso aos reforçadores, predominantemente, por duas vias: porque lhe são dados espontaneamente ou porque exige que lhe dêem. Na primeira condição, surge uma relação distorcida da realidade: aquilo que obtém não é produto de seus comportamentos, mas de alguém que se antecipa para provê-los. Fere-se, assim, o paradigma operante:

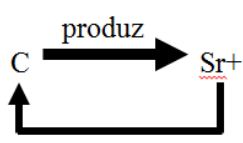

Este paradigma é substituído por outro, como se segue:

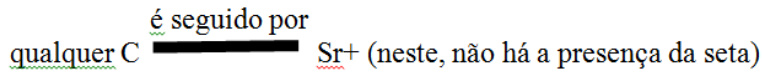

Desta maneira, há um déficit generalizado crônico de comportamentos e um enfraquecimento na emissão dos que persistem, os quais, em geral, não são percebidos. A pessoa não está consciente de que o acesso aos reforços se dá pelo fato de ele, tão somente, existir em determinado e restrito ambiente social (em geral, a família e só ela pode disponibilizar os reforços livres, pois foi treinada por alguém ou treinou esse alguém para que assim fosse) e não por meio de comportamentos, que são selecionados diferencialmente por uma ampla comunidade sócio verbal, que permite acesso aos reforços disponíveis (não cedidos livremente), de acordo com práticas culturais 
particulares. A primeira condição torna a pessoa poderosa em um pequeno mundo; a segunda a integra harmoniosamente em um mundo amplo. Aquele que é dependente tem sentimentos de autoconfiança (que são exagerados e irreais), desconectados de comportamentos de autoconfiança (que são precários ou inexistentes).

$\mathrm{Na}$ segunda condição, comportamentos de exigir de pessoas de seu grupo social restrito que lhe dêem o que quer, produzem as consequências (trata-se de um padrão compatível com o paradigma operante); no entanto, emitir tais comportamentos não significa ter habilidades para produzir as consequências, independentemente de outra pessoa. Assim, por exemplo, a pessoa veste-se com as roupas de sua escolha, porque assim ela exige e é atendida por alguém, no entanto não fazem parte de seu repertório comportamental os elos do encadeamento que se estendem desde produzir o dinheiro para poder comprar a roupa até os elos de ir a uma loja, escolher aquelas que deseja e pagar por elas com dinheiro que produziu. Veja o paradigma que se segue:

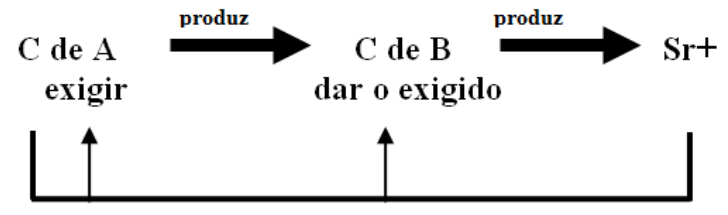

Paradigma de dependência do outro

Em ambas as condições, a pessoa tem sentimentos de autoconfiança, que se confundem com sentimentos de desejar ter e, nas duas condições, estão ausentes comportamentos que produzem as consequências, sem a mediação arbitrária feita por outra pessoa. Desta forma, alterada a composição social presente (morte dos pais, por exemplo), a pessoa sente-se desamparada e incapacitada para ter acesso aos reforçadores. Havendo persistência de tais condições no tempo, a pessoa progressivamente passa a ser mais diferente comportamentalmente de outras da sua faixa etária, classe social etc... e, inevitavelmente, vêse como um "pássaro pintado", distinto do seu bando. Inicia-se aí um processo de fuga e esquiva em que a pessoa pode formular uma autorregra alienada, tal como: "Eu sou mais eu...", que comportamentalmente significa "se continuar a me comportar como sempre agi, então as consequências reforçadoras ser-me-ão apresentadas." Mais parece um pensamento mágico! O fato é que tal autorregra sofre o processo de extinção; comportamentos de esperar por alguém que o reforce ou de solicitar a outro alguém, que não faz parte do grupo, que o privilegiava com reforços, enfraquecem-se e surgem sentimentos próprios do processo de extinção: raiva, agressividade, desânimo, desespero, depressão, desamparo, abulia, isolamento, perda de apetite, descuidos com higiene, doenças e morte. A pessoa passa a expressar sintomas, os mais comuns dos quais são: depressão, fobias, ataques de pânico, pensamentos suicidas, ruminações depreciativas sobre o sentido da vida e o significado das pessoas, isolamento social. Justamente ele que precisa do social para sobreviver não consegue se incluir no social. Sem ter, não consegue ser. Todas essas queixas compõem um quadro afetivo e comportamental pouco sensível a intervenções psicoterapêuticas, pois o déficit generalizado de repertório de comportamentos é obstáculo restritivo para a implementação de estratégias psicoterapêuticas.

\section{"No tempo em que festejavam o dia dos meus anos.. Que meu amor, como uma pessoa, esse tempo! \\ Desejo físico da alma de se encontrar ali outra vez, Por uma viagem metafísica e carnal, Com uma dualidade de eu para mim... \\ Comer o passado como pão de fome, sem tempo de manteiga nos dentes!}

Vejo tudo outra vez com uma nitidez que me cega para o que há aqui...

A mesa posta com mais lugares, com melhores desenhos na loiça, com mais copos,

$O$ aparador com muitas coisas - doces, frutas, o resto na sombra debaixo do alçado -,

As tias velhas, os primos diferentes, e tudo era por minha causa,"

Tais versos sintetizam a dor de perder o que se teve e a impotência para reavê-lo por si mesmo!

$\mathrm{O}$ que ocorre com os sentimentos de autoestima? Aparecem na forma de autorregras, tais como: "Tudo me dão, porque me amam"; "Não suportam me ver sofrer"; "Eles têm dinheiro, influência social, poder, isso tudo também me pertence..." etc. No entanto, tais sentimentos não bastam para produzir comportamentos e sentimentos de autoestima. Há duas condições que interagem entre si na gênese da autoestima: ter repertório para produzir consequências reforçadoras positivas e evitar consequências aversivas sem mediação de outra pessoa (essas circunstâncias produzem comportamentos e sentimentos de autoconfiança: "Eu sei o que tenho de fazer para alcançar minhas metas, desde as menores...”). Faltalhe agora sentir que ela é amada não por causa de seus comportamentos necessariamente, mas por existir (por exemplo, a avó quando encontra o netinho não lhe pergunta o que fez de bom para beijá-lo, simplesmente beija o neto, cheira seu cabelo suado e diz: "Como eu te amo!’). A combinação inseparável destas duas condições gera autoestima; a primeira provoca competência e vazio afetivo e a segunda, sentimentos de ser querida, mas na dependência do outro. Juntas se complementam. O reforço livre, até certo ponto, só privilegia a segunda alternativa e dá origem ao arrogante incompetente. Assim, há necessidade de a pessoa ter bens que possam ser transformados em admiração ou submissão dos que o cercam na vida social.

Dessa forma,, por exemplo, carro luxuoso, relógios de marca, uma casa na praia, oportunidades para programas sociais que produzem abundantes sensações agradáveis, cartão de crédito sem limite (reforços sensoriais) etc., são elementos ardilosamente usados como instrumentos de controle sobre o outro, meios de conquista de "amigos", de garotas que se aproximam com objetivos suspeitos, que o bajulam, se oferecem como companhias, 
se antecipam para "juntos" organizarem festas etc. A pessoa bajulada recebe muita atenção que atrapalha a discriminação: gostam de mim ou do que lhes proporciono? A pessoa sente-se querida, mas na verdade se questiona: então, a autoestima é um sentimento fugaz, porque a suspeita sobre o porquê as pessoas se aproximam dele e os comportamentos de autoestima, tal como liderar atividades para curtir a vida com um grupo que o adora (assim ele tenta pensar e tenta sentir) são comportamentos necessários para manter esses indivíduos por perto, mas que ferem o pressuposto de que os reforços sociais devem ser livres de contingências para despertar sentimentos e comportamentos de autoestima; nessas condições são, pois, ao contrário de gratuitos e espontâneos, conquistados. Paga-se para tê-los. Não existem, de fato, "Eu sou amado", mas "Eu posso" e estas duas expressões são confundidas. Não existe discriminação, por exemplo, entre duas condições nas interações sociais: "Eu manipulo as pessoas pelo que eu tenho ou demonstro ter" é um pensamento descartado, substituído por "As pessoas adoram minha companhia; consideram-me especial..."

$\mathrm{O}$ indivíduo, na realidade, não testa ser discreto em relação ao que tem; o exibicionismo pode ser conceituado como comportamento de fuga e esquiva, que o protege de entrar em contato com o que aconteceria se as aproximações das pessoas fossem regidas pelo que essa pessoa é (como se comporta) e não pelo que ostenta ser. Poder financeiro não é o único instrumento de controle sobre o outro, pois há outras fontes de poder: beleza, status político, força física, conhecimento, idade etc. As interações sociais devem ser reguladas por CR amenas, sem o objetivo de submeter o outro! Tal déficit de discriminação produz um equivocado sentimento de autoestima; (Acredita que o amam e não se dá conta que assim se comportam porque as subjuga com suas oferendas); logo, a pessoa possui um repertório de comportamentos de autoestima restrito a um punhado de "pessoas amigas". Os comportamentos de anfitrião de prazeres são de esquiva da condição aversiva de ser deixado só; então, é-lhe difícil abrir mão do controle exercido pelos atos de compartilhar seus bens e, desta forma, testar a realidade. Deixar de ser um patrocinador de bons momentos é para ele muito arriscado. E o ciclo se repete: precisa ter e compartilhar o que tem, para se sentir bem com as pessoas. A autoestima é ficcional! Para se chegar a ter ciência de que é realmente querido, a rotina da pessoa tem de se deslocar para caminhos árduos que incluem quebrar o ciclo vicioso: produzir o que tem, compartilhar com os outros que o cercam em condições de igualdade, manter-se cuidando de sua saúde (por exemplo, envolvendo-se com atividades físicas saudáveis e afastando-se de vícios), engajando-se em atividades profissionais sérias com responsabilidade, dentro das regras do ambiente profissional; manter relacionamento afetivo estável, ser produtivo sem a mediação do outro e, por que não, curtir a vida dentro desses limites.

Burlar a relação operante gera sentimentos de vazio existencial, depressão, sensação de insaciabilidade, fobias, isolamento, desdém pela vida, indiferença às pessoas. Quem tem acesso a privilégios sem se comportar para produzi-los não aprende a se amar, nem a amar o próximo, nem mesmo a amar o que a vida lhe proporciona. Mantém-se basicamente como um organismo que sobrevive; não se transforma significativamente em uma pessoa que se desenvolve.

A possibilidade de comportar-se e, tão somente desta forma, produzir reforços positivos, torna o Homem um ser pleno e promove a sobrevivência do grupo social. Cabem duas asserções de Skinner, as quais sintetizam o necessário papel funcional do ser humano como sujeito de sua história e como objeto das consequências que - como sujeito - ele produz: "O comportamento reforçado positivamente se mostra pela participação ativa na vida, livre de tédio e depressão." (Skinner, 1969,) e "Um mundo meramente feliz não é suficiente; deve ser um mundo que tenha chance de sobreviver." (Skinner, 1983, p.395)

$\mathrm{O}$ que resta àquele que depende de reforços livres quando os autores de sua vida param de se comportar? Os versos a seguir bem ilustram o desfecho:

\section{"No tempo em que festejavam o dia dos meus anos... Pára, meu coração! Não penses! Deixa o pensar na cabeça! ó meu Deus, meu Deus, meu Deus! Hoje já não faço anos. Duro. Somam-se-me dias. Serei velho quando o for. Mais nada. \\ Raiva de não ter trazido o passado roubado na algibeira! \\ O tempo em que festejavam o dia dos meus anos!"}

\section{Indiferença afetiva pelo outro.}

Amar não é apenas sentir, mas também comportar-se em relação ao outro; não é apenas um comportamento-sentimento, (as classes de respostas de agir e de sentir nunca se expressam separadamente), mas também um conjunto inter-relacionado de muitas diferentes classes de comportamentos determinados por redes de contingências de reforçamento que se influenciam reciprocamente (Guilhardi, 2019). Capacidade para vir a amar é um potencial do Homo Sapiens, no entanto tal potencial não se converte em comportamentos na ausência de CR que instalam, mantêm e ampliam as classes de comportamentos. Assim, a capacidade de amar de uma pessoa é determinada pela sua história de contingências e pela ação presente das contingências atuais, provindas da comunidade sócio verbal (família, escola, religião, amigos etc.) a que a pessoa pertence e no seio das quais se desenvolveu e vem se desenvolvendo. Amar inclui comportamentos operantes e respondentes, com prevalência dos operantes: amar não é comportamento reflexo, embora inclua reflexos respondentes. Assim, parece compreensível que pais que tudo dão para seu filho suponham que serão especialmente amados por tamanha bondade! O comportamento não é regido pela lógica, mas por contingências de reforçamento e contingências de reforço livre - exatamente pelo fato de que boicotam a 
interação em que comportamento produz reforçamento limitam significativamente interações de amor!

A necessária passagem que a comunidade sócio verbal deve fazer acontecer do efeito de satisfação do reforçamento para o efeito de fortalecimento de comportamento é complexa, conforme já foi exposto. Essa passagem exige muita perspicácia da agência de controle, razão por que deveria ser alertada explicitamente por profissionais comportamentais sobre a necessidade essencial desta transição, principalmente, porque os efeitos perniciosos do reforço livre se expressam com atraso para servir como controle imediato de ações perigosas. $\mathrm{O}$ perigo não está localizado apenas nas ações arriscadas, inconsequentes da pessoa que recebe reforço livre, mas também nos comportamentos daqueles que propiciam o reforço livre, porque, ao contrário do que afirmam, tendem a persistir na manutenção das interações com reforço não contingente. São interações recíprocas que se ajustam de acordo com conveniências prejudiciais para todos os envolvidos no processo.

Desde a infância, o reforço livre é manejado por uma agência de controle (em geral, os pais) que, inadvertidamente, selecionam comportamentos de contracontrole para o filho, que passa, assim, a ocupar o papel de controlador em relação aos pais: exige, agride, ameaça, seduz, chantageia etc. e obtém o que deseja. Os comportamentos contracontole de controle do garoto, enquanto ele se desenvolve, generalizam-se para outros contextos e para outras pessoas (professores, colegas de classe, pessoas de um modo geral). Nem sempre os contextos sociais, fora do ambiente familiar, atendem às exigências, enfrentamentos, quebra de regras etc. da criança - agora adolescente, depois adulto - e surgem conflitos: expulsão da escola, multas no trânsito, advertências em ambientes públicos, discussões no trabalho, demissões etc. Os próprios pais passam a não ter recursos financeiros (ou desistem de disponibilizá-los) para atender os gastos do filho, não conseguem controlar a agressividade dele etc. e pedem ajuda. As relações de controle e contracontrole de controle tornam-se temas de conflito entre as partes e prevalecem contingências aversivas, difíceis de evitar, até mesmo de amenizar.

Citação de Skinner (1975/1978):

"Se [quisermos mudar tais condições aversivas sobre os quais perdemos o controle] nós precisamos daqueles reforços que adquiriram poder especial na evolução da espécie. E para piorar, muitos desses reforços foram exatamente as coisas dadas no ato de ajudar ou cuidar das pessoas - as coisas garantidas como direitos [Skinner insiste no perigo de as pessoas se sentirem no direito de ganhar, que é incompatível com produzir para ter] [...] $\mathrm{O}$ indivíduo tem, portanto, de ser privado em alguma extensão e, consequentemente, se ver em situação de não ser ajudado ou de lhe serem negado alguns direitos. Não podemos evitar este conflito, enquanto continuarmos a ver ajuda como dar bens ao invés de programar contingências de reforçamento." [grifos nossos, adicionados] (p. 41)

Alguém pode lembrar que a associação sistemática entre estímulos pode gerar novas funções de estímulo. Os pais, ao darem bens, não se tornam estímulos reforçadores condicionados? Podem vir a ser, porém isso não significa que o filho os amará por esse procedimento.

Vamos entender o que ocorre. Quando os pais, dizem "sim", tornam-se SD, diante dos quais pedir é reforçado pelo bem solicitado. O prazer resultante de ter adquirido o bem é efêmero, porque não foi produzido por comportamento, logo o comportamento de produzir não é instalado, apenas o de pedir. Logo em seguida, deseja-se outro bem, e os pais - apenas nesta circunstância tornam-se novamente $\mathrm{SD}$, e novo pedido é feito e atendido. Quando os pais dizem "não", tornam-se estímulos aversivos, (poderão vir a cercear o acesso ao que o filho deseja), o que desperta imediatamente comportamento de fuga e esquiva que, em ocasiões anteriores, converteram o "não" em "sim". A cada ocorrência de um "não", esses comportamentos de fuga e esquiva tornam-se mais intensos, mais aversivos para os pais, que, invariavelmente, voltam para o "sim", e o ciclo pernicioso se agrava-se. Os comportamentos de fugaesquiva são agressões dirigidas aos pais, ameaças, tais como "Vou sair por aí e detonar o meu carro e minha vida que se f..."; "Já sou infeliz e se vocês me tiram tudo, para que viver?" (Um cliente disse esta frase diante dos pais, segurando um revolver contra a cabeça!); "Vocês querem me isolar, que eu não tenha mais amigos, mas eles não são culpados pelo que eu sou; os culpados são vocês!" Convenhamos que são situações extremas, mas infelizmente, não raras. Tais ciclos (pedir e ganhar; exigir e ganhar) repetem-se de tal maneira, que o $\mathrm{SD}$ e o $\mathrm{S}$ préaversivo têm funções efêmeras. Acrescente-se que o filho não tem no seu repertório comportamental outras classes de comportamentos, ditas desejadas, operando nas interações.

Assim, amar, ser grato, retribuir, respeitar, cuidar, cooperar etc. são comportamentos muito complexos, que precisam ser instalados e mantidos por duradouras, sistemáticas e intrincadas contingências de reforçamento, que interagem e que, portanto, se influenciam entre si. Todas essas classes comportamentais incluem autocontrole, tolerância à frustração, manutenção de comportamento, mesmo com reforçamento atrasado, emissão de longas e complexas cadeias de comportamentos para produzir um bem, comportar-se de acordo com normas e regras, mudança da rotina de vida cotidiana, afastamento dos "amigos" que mantêm os excessos do filho etc., lembrando que quase todos esses comportamentos - que são opostos às características de uma pessoa prioritariamente mantida por reforço livre não foram devidamente instalados durante a história de contingências da pessoa. Não será possível instalá-los agora com a necessária urgência. $O$ papel, como já se disse, de um psicoterapeuta comportamental, atuando como mediador e usando procedimentos de mudanças 
graduais dos comportamentos das duas partes envolvidas, pode ser uma importante ajuda. Será mais fácil levar adiante com sucesso tal mediação, se o filho aprendeu a amar seus pais.

Voltamos à questão conceitual: quem dá não é amado por quem recebe? Não se conclua que assim é: pode ser que sim, pode ser que não; depende da história de contingências que regularam as interações entre eles. No exato momento em que recebe o bem, o filho sente prazer, satisfação, assim como uma pessoa com posses, mas com uma vida vazia de reforços contingentes; sente-se bem quando compra um carro novo, ou joias, ou roupas da moda, embora ela, em um curto momento posterior, volte a sentir um vazio existencial que não se resolve acumulando bens... Portanto, tanto o bem recebido quanto o benfeitor que proveu essa vantagem têm valor reforçador passageiro. A satisfação e o prazer são efêmeros. $\mathrm{O}$ processo de vir a ter um bem, neste caso, assemelha-se ao de consumir uma droga. Passado o efeito, vem o vazio e mais necessidade dela. Assim, nas interações entre aquele que dá e aquele que recebe surgem algumas interpretações de antagonismo, como o doador que vê o beneficiado como ingrato; o beneficiado considera o provedor mesquinho, e as farpas tornam-se mais afiadas e dolorosas. Além disso, há muitas contingências operantes no dia a dia que competem para quebrar a simples relação entre eles. O "garotão" precisa o tempo todo impressionar a comunidade que o cerca de que tem, de que pode (sem de fato ter, e de fato pouco poder...). Ocorre que a comunidade logo se cansa de vê-lo bem vestido e com "anexos" caros (moto, carro etc.) e ele, assim precisa mais! Tudo, neste caso é efêmero. Para iludir o efêmero é preciso mais, mais do supérfluo!

As interações sociais são regidas fundamentalmente pelas leis do condicionamento operante (não exclusivamente, convém lembrar!). A pessoa que libera os reforços livres torna-se um SD, cuja presença é marcada pela ocasião em que emitir classes de respostas de pedir, de exigir, começar a apresentar queixas, tais como fobias, depressão, mal-estar etc. A consequência é a obtenção dos privilégios desejados, mas, conforme já explicitado anteriormente, a resposta para ser reforçada depende do outro como mediador, ou seja, a relação social estabelecida é de dependência de um outro. Surge, então, uma interação conflituosa: "Dependo de você para ter, logo não sou livre de você". Decorre daí outro conflito: "Não posso ter tudo que desejo... porque você não me provê tudo! Logo, você me limita e me frustra!" Esse processo leva a um desfecho que pode ser resumido em: "Gosto de você pelo que me dá; detesto você pelo que me nega". A interação entre estas pessoas é regida pelas coisas que resultam da mediação da interação. Eventualmente, o filho pode afirmar: "Amo meus pais..." Não se trata necessariamente de amor, mas de dependência para alcançar suas necessidades. Enquanto não as preenche, o outro lhe parece ser importante - daí a afirmativa "o amo" -, mas uma vez satisfeita a necessidade, segue-se o desdém do saciado. Por outro lado, qualquer recusa desperta reações agressivas, exigências enfáticas sem quaisquer manifestações de empatia ou compreensão pelo outro, que lhe nega.

Como escreveu Skinner (1986, 1987):

"Práticas culturais, que promovem os efeitos prazerosos das consequências do comportamento às custas dos efeitos de fortalecimento têm deteriorado contingências de reforçamento.” [...] (p. 18)

\begin{abstract}
"Muitas práticas de culturas avançadas parecem aumentar a frequência de reforço imediato. O mundo ocidental é especialmente rico em coisas que chamamos de interessantes, bonitas, gostosas, divertidas, excitantes. Estas coisas tornam o dia a dia mais reforçador, mas elas reforçam pouco mais do que o comportamento que coloca alguém em contacto com elas. [...] o problema [...] não é que há reforços excessivos, mas sim que eles não são contingentes sobre os tipos de comportamentos, que nutrem o indivíduo ou promovem a sobrevivência da cultura ou da espécie.” (p. 24)
\end{abstract}

Neste ponto, cabe uma distinção importante: a pessoa doadora torna-se SD para o outro emitir o comportamento de pedir, mas não se torna SD para sentir afeto por ela, que lhe dá.... Tal condição não produz amor, nem respeito, nem admiração... Em situação de extinção, ocorre agressão e desdém por aquele que foi (mas deixou de ser) fonte de reforços. Reconhecimento, gratidão, amor não são classes de comportamentos selecionados em relações de reforço livre! O que realmente importa é o acesso ao reforço (na verdade qualquer mediador serve, desde que tenha desempenho funcional: gere o reforço. Não importa quem é o "aviãozinho" que fornece a droga; importa a droga em seu poder). Adicionalmente, quando o doador não fica sob controle de qualquer resposta específica, antecipa-se e dá o privilégio, não se estabelece uma relação operante legítima: a pessoa que doa não é SD. Sentir afetos positivos por aquele que dá acesso a reforços, que se manifestam na forma de amar tal pessoa, ser grato a ela, reconhecer os valores que ela tem, respeitá-la como pessoa, cooperar com ela, desejar estar ao lado dela e sentir-se bem com ela (mesmo quando ela não está provendo privilégios), são classes muito complexas e amplas de comportamentos, as quais precisam ser instaladas uma a uma por CR específicas, muitas das quais resultam em repertório comportamental de terceiro nível de seleção.

$\mathrm{O}$ mediador do reforço livre quase nunca gera CR que produzem afetos positivos em relação a ele próprio. Esperar que alguém o ame, valorize-o, sinta gratidão etc. pelo simples fato de dar-lhe bens é ingênuo. Comportamentos e sentimentos tão complexos, como amar, valorizar (o outro), sentir gratidão etc., precisam ser sistematicamente instalados e mantidos por $\mathrm{CR}$, manejados pela comunidade socioverbal próxima do indivíduo. Tais CR não estão presentes nas interações 
caracterizadas pelo reforço livre! Não confunda, portanto: quando alguém recebe algo que lhe é gratificante pode sentir prazer, satisfação, alívio etc., que são sensações corporais, mas que se distinguem de sentimentos: sentir é uma classe complexa de comportamentos, instalada por CR complexas, que interagem entre si e são produzidas por uma comunidade verbal. Com relação à espécie, o ser humano tem sensações corporais e, para tal, não precisa de uma comunidade socioverbal para responder a elas, pois sensações pertencem ao primeiro e segundo níveis de seleção, os quais não privilegiam o outro. No entanto, sem ser exposta a influências específicas de uma comunidade verbal, a pessoa responde ao que sente, mas não responde necessariamente ao contexto que a leva a sentir...

Assim, algo que é gostoso pode controlar o comportamento de produzi-lo novamente, mas não é essencial saber que aquilo é gostoso. Tal consciência é produto social. Apenas enquanto membro de um grupo socioverbal, a pessoa pode adquirir comportamentos de sentir, que precisam ser instalados como qualquer outro. Tal aquisição envolve: 1. Identificar a presença dos comportamentos e o que sente no seu corpo e, para isso, a comunidade deve lhe perguntar: "O que você está sentindo?" e definir consequências diferentes para as respostas verbais de descrever o que sente. 2. Aprender a relacionar o que faz e o que sente quanto a eventos ambientais antecedentes, os quais a levam a emitir respostas e a sentir o que isso causa no seu corpo. Ao relacionar atividades ou respostas com eventos que as evocam, a pessoa está dando o segundo passo para identificar (relações específicas entre seu organismo e o ambiente que lhe é funcional, ou seja, a comunidade verbal deve levar a pessoa a relacionar o que sente com as contingências de reforçamento que produzem tal sentir. A comunidade ensina seus membros a fazer tais relações perguntando: "O que aconteceu ou está ocorrendo que leva você a fazer o que está fazendo e a sentir o que está sentindo?" Permitir uma compreensão mais completa de tudo que está ocorrendo com a pessoa. A pergunta é o que o comportamento que emitiu produziu: foi bom, fez bem, aumentou a probabilidade de vir a fazê-lo novamente, o que você sentiu ao ter contato com as consequências de sua ação?

Assim, completam-se as três colunas da tríplice contingência não apenas como descrições isoladas uma das outras, mas também como se integram em um conjunto único de determinações entre o que me leva a fazer e sentir (antecedente), o que fiz e senti (organismo, comportando-se), o que meus comportamentos produziram (consequências) e como estas interações influenciam meu comportamento e o que passei a sentir. Finalmente, resta dar um nome à descrição e interpretação da tríplice contingência. A interpretação exige a análise e a identificação das funções de cada elemento da CR e só podemos nomeá-la depois que tiver identificado tais funções. Assim, por exemplo, "Esta condição causa medo, porque sinaliza uma ameaça (antecedente), não sei como enfrentá-la (déficit de comportamentos) e, sendo assim, acontecerá algo aversivo (consequência). Trata-se de uma
CR coercitiva (aversiva) e como não há repertório comportamental de fuga e esquiva, que elimina, pospõe ou enfraquece a consequência aversiva, ocorre a emissão de respostas erráticas (sem função naquele ambiente específico), ou a paralisação (uma redução ampla e generalizada de respostas operantes) com reações respondentes intensas, denominadas de ansiedade e medo! 3. Aprender a nomear os comportamentos de sentir, para os quais a comunidade verbal deve dar modelos de termos, que têm a função de tactos verbais sob controle de comportamentos de sentir, evocados por determinados contextos ambientais, que são, tecnicamente falando, as contingências de reforçamento. No exemplo, a CR pode ser denominada de supressão condicionada modelo experimental da produção de ansiedade (Estes e Skinner, 1948). Todo esse processo de identificação, descrição, análise e nomeação da CR deve ser feito na ausência de ajuda de pessoas da comunidade verbal. Falamos, então, em autoconhecimento: a pessoa identifica o que sente ou como se comporta, relaciona tal sentir e comportar-se com as contingências de reforçamento das quais são função e as nomeia, utilizando termos convencionados pela comunidade verbal.

\section{EM SUMA...}

Importante característica comportamental que foi selecionada na espécie Homo Sapiens - que interessa ao tema em discussão - é a convivência grupal. As pessoas sobrevivem graças às interações entre os membros do grupo humano. Os comportamentos de um membro do grupo têm várias possíveis funções de evento antecedente para comportamentos de outros membros, bem como têm, adicionalmente, várias possíveis funções de evento consequente. Tais CR contribuíram para a sobrevivência do indivíduo, bem como para a sobrevivência do grupo. O ser humano não teve, como membro de uma espécie, a alternativa de sobreviver nem de se desenvolver isoladamente de outros membros da mesma espécie. As novas configurações entre CR, que surgiram com a progressão da vida em grupo (com a evolução da Cultura), alteraram as influências interacionais entre os membros da espécie, mas nem sempre tais configurações serviram ao propósito de melhorar o indivíduo nem o grupo conforme foi alinhavado em linhas acima -, de tal maneira que alguns indivíduos se beneficiam dos comportamentos dos outros a curto prazo, mas pouco ou nada contribuem para ganhos dos outros e, a médio e longo prazo, todos perdem! O principal prejuízo recai, em dois aspectos, sobre aquele que se tornou dependente:

1. Quebra-se a relação operante, em que comportamento produz consequência, o que resulta, conforme já foi assinalado, em déficits de comportamentos e sentimentos devastadores, assim como a consequente dependência do outro para sobreviver e se desenvolver. "Nós não somos necessariamente felizes porque temos tudo o que queremos. A palavra saciado está relacionada à palavra triste." (Skinner, 1969, p. 36) 
2. Impõem-se um isolamento social que se caracteriza pela quebra de reciprocidade: uma pessoa é cuidada pelo grupo social, mas não cuida do seu grupo. Dessa ruptura, decorrem duas consequências:

a. Os cuidadores do indivíduo compõem um grupo restrito (pais, irmãos...) que, quando se tornam impossibilitados de manter a função de proteção, não são substituídos por outros membros da sociedade, pois estes não oferecem o excesso de proteção de que o indivíduo passou a necessitar;

b. O indivíduo dependente torna-se alheio aos demais membros do grupo, exceto em relação àqueles comportamentos do outro, que lhe trazem benefícios diretos. Tal indiferença inclui uma completa apatia afetiva em relação ao outro, quer seja o outro que está próximo, quer seja aquele que está distante, a qual resulta em isolamento do indivíduo, exatamente ele próprio que mais necessita de interações sociais. O cuidador sentese pouco amado, sente-se usado e, finalmente, passa a sentir-se impotente, pois não consegue ajudar de forma eficaz o ser que se tornou dependente e, eventualmente, adoeceu. Adicionalmente, o próprio indivíduo é seriamente prejudicado em seu desenvolvimento global (comportamental e afetivamente), pois não se define como membro de um grupo socioverbal, ferindo uma característica básica dos indivíduos da espécie Homo Sapiens.

\section{DECLARAÇÃO DE CONFLITO DE INTERESSES}

O autor declara que não há conflito de interesses relativos à publicação deste artigo.

\section{DIREITOS AUTORAIS}

Este é um artigo aberto e pode ser reproduzido livremente, distribuído, transmitido ou modificado, por qualquer pessoa desde que usado sem fins comerciais. O trabalho é disponibilizado sob a licença Creative Commons 4.0 BY-NC.

\section{(cc) EY-NC}

\section{REFERÊNCIAS}

Estes, W. K. \& Skinner, B. F. (1999). Some quantitative properties of anxiety. In Cumulative record (Definitive Ed., pp. 558-569). Acton, MA: Copley (Publicação original 1941).

Guilhardi, H. J. (2002a). Autoestima, autoconfiança e responsabilidade. In M. Z. S. Brandão, F. C. S. Conte, S. M. B. Mezzaroba (Orgs.), Comportamento Humano - Tudo (ou quase tudo) que você precisa saber para viver melhor. Santo André, SP: Ed. ESETec.

Guilhardi, H. J. (2019). Interações amorosas sob uma perspectiva comportamental. Disponível no site http://www.itcrcampinas.com.br/
Pessoa, F. (1995). Obra poética (p. 379). Rio de Janeiro: Editora Nova Aguilar.

Skinner, B. F. (1969). Contingencies of reinforcement -A theoretical analysis. New York: Appleton.

Skinner, B. F. (1978). The ethics of helping people. In Reflections on behaviorism and society (33-47). Englewood Cliffs, N. J.: Prentice Hall. (Publicação original 1975).

Skinner, B. F. (1987). What is wrong with daily life in the western world? In Upon further reflection (pp. 15-32). Englewood Cliffs, N. J.: Prentice Hall. (Publicação original 1986).

Skinner, B. F. (1987). News from nowhere. In Upon further reflection (pp. 33-50). Englewood Cliffs, N. J.: Prentice Hall (Publicação original 1985).

Skinner, B. F. (1999). "Superstition" in the pigeon. In Cumulative record (Definitive Ed., pp. 570-574). Acton, MA: Copley. (Publicação original 1948).

Submetido em: 25/03/2019 Aceito em: 27/06/2019 